\title{
Damaged Type and Areopagitica's Clandestine Printers
}

\author{
CHRISTOPHER N. WARREN, \\ PIERCE WILIAMS, \\ SHRUTI RIJHWANI, \\ AND MAX G'SELL \\ Carnegie Mellon University
}

\begin{abstract}
Milton's Areopagitica (1644) is one of the most significant texts in the history of the freedom of the press, and yet the pamphlet's clandestine printers have successfully eluded identification for over 375 years. By examining distinctive and damaged type pieces from roo pamphlets from the I640s, this article attributes the printing of Milton's Areopagitica to the London printers Matthew Simmons and Thomas Paine, with the possible involvement of Gregory Dexter. It further reveals a sophisticated ideological program of clandestine printing executed collaboratively by Paine and Simmons throughout 1644 and I645 that includes not only Milton's Areopagitica but also Roger Williams's The Bloudy Tenent of Persecution, William Walwyn's The Compassionate Samaritane, Henry Robinson's Liberty of Conscience, Robinson's John the Baptist, and Milton's OfEducation, Tetrachordon, and Colasterion.
\end{abstract}

KEYWORDs Areopagitica, print culture, liberty of the press, tolerationism, typography

\section{INTRODUCTION}

For a tract fundamentally about "the Liberty of Unlicenc'd Printing," there remains a deep irony surrounding what we know about Areopagitica. After roughly 375 years, we still don't know who printed it. ${ }^{1}$ Issued clandestinely in late November 1644, the six-sheet, 40-page Areopagitica appeared with neither the mandatory license that prompted its writing

DOI: 10.5325 MILTONSTUdiES.62.1.0001

Milton Studies, Vol. 62, No. 1, 2020

Copyright (C) 2020 The Pennsylvania State University, University Park, PA 
nor the name of the printer who had colluded with Milton in the crime. Milton's name appears boldly on Areopagitica's title page, but it is one of the great ironies of cultural and political history that the printer responsible for this "first expression of the idea of press freedom written in the English language" - the individual(s) who even more than Milton risked their livelihoods in printing it - have never been definitively identified. ${ }^{2}$ The purpose of this article is to present new evidence for two and possibly three of the individuals responsible for printing Areopagitica. Research for this article has resulted in related discoveries concerning the anonymous printing of Milton's OfEducation (June I644), Tetrachordon (March I645), and Colasterion (March 1645). Happily, unraveling the evidence of who printed Areopagitica also allows accounts of who printed the first editions of several other significant tolerationist tracts dating from the months immediately preceding Areopagitica's publication-Roger Williams's The Bloudy Tenent of Persecution, William Walwyn's The Compassionate Samaritane, Henry Robinson's Liberty of Conscience, and Robinson's John the Baptist. By updating postwar bibliographic methods for the age of digitized books, we present evidence indicating the roles of London printers Matthew Simmons, Thomas Paine, and Gregory Dexter in Areopagitica. And yet, as we shall see, the typographical evidence raises nearly as many questions as it answers.

\section{Anonymous Printing and the Evidence of Damaged Type}

Before turning to I640s print culture, it is helpful to situate the study of damaged type in the post-World War II academy. In 1959 Ernest Sirluck wrote in the headnote to his magisterial Yale Prose edition of Areopagitica that, "although it bears Milton's name on the title page, [Areopagitica] was unlicensed, unregistered, and issued without imprint of publisher or printer (who remain unknown)." ${ }^{3}$ While Sirluck's edition-forged in the fires of postwar McCarthyism and Cold War liberalism-has now nourished several generations of Miltonists, it predated by a few years another monument of postwar scholarship, Charleton Hinman's The Printing and Proof-Reading of The First Folio of Shakespeare (1963), whose methods, had they been sufficiently known and developed, might well have been brought to bear on the question of Areopagitica's printing. ${ }^{4}$ As Stephen B. Dobranski observed in 1999, Milton scholarship has long downplayed "the material processes of textual production" in a way dissimilar from Shakespeare scholarship. ${ }^{5}$ 
The asynchronous timing of these two postwar scholarly monuments may be one reason why.

Hinman, in search of (as he avowed) "what Shakespeare actually wrote," radically transformed scholars' understanding of Shakespeare's First Folio through an ingenious method and startling results. Inspired by wartime approaches to aerial photography, Hinman developed his famous Hinman Collator (fig. I), which allowed him to compare First Folio press variants much as military strategists had compared before and after photos to assess troop movements. ${ }^{6}$ Hinman was able to reconstruct with a precision never before imagined the detailed chronologies of casting off, typesetting, and proof correction and their consequences for Shakespearean texts.

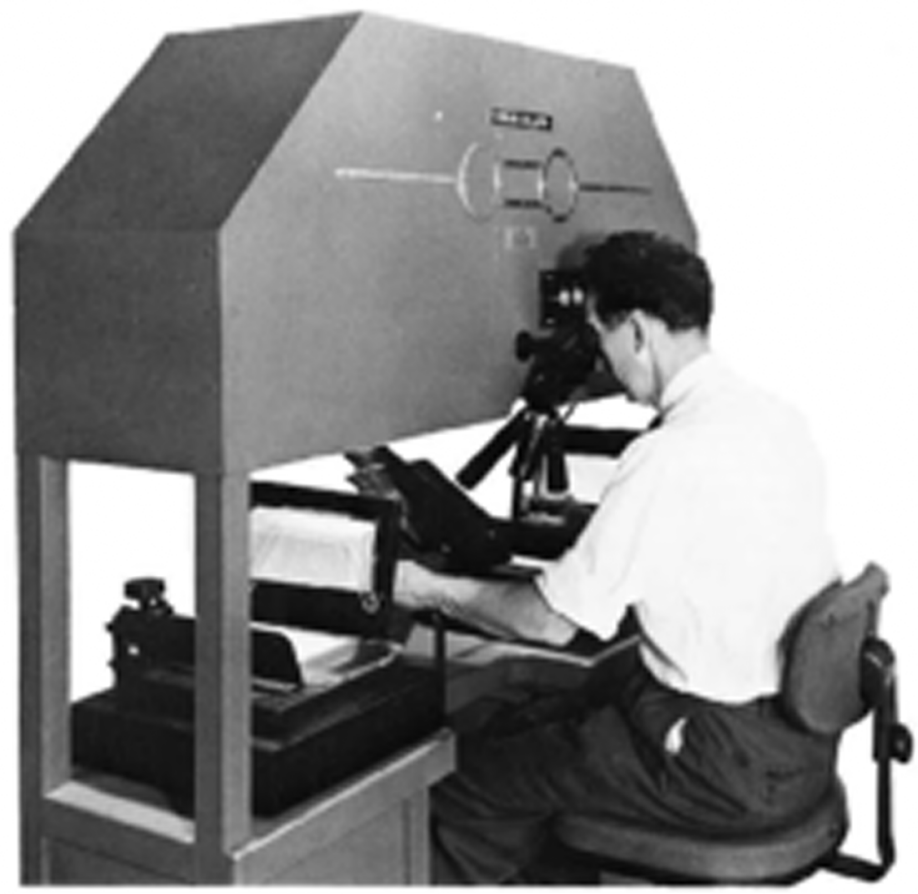

Figure I Promotional brochure for the Hinman Collator produced by Mico Engineering Company, 1973. Courtesy of the Folger Shakespeare Library. 
Hinman's painstaking work influenced a generation of Shakespearean editors and textual critics, perhaps most notably Peter Blayney, but a key aspect of this work was a relatively new kind of evidence, the evidence of damaged or distinctive type. By identifying the specific quires in which damaged pieces of type reappeared, Hinman was able to posit for the first time that the First Folio had been set by formes rather than in successive pages, and that this fact had wide implications for editorial decisions. Because pages 6 and 7 of each I2-page quire were composed before pages $\mathrm{I}^{-} 5$, it became possible to see how the compositors' attempts to fit copy to the available space had influenced the text that ultimately appeared on the printed page. ${ }^{7}$

Hinman's method was certainly of its moment. If, as Jeffery Masten has suggested, Hinman's parallel interest in profiling compositors "[bore] resemblance to, and [was] startlingly contemporaneous with" McCarthyite "attempts to monitor and detect ... sexual identities," the unusual sensitivity to the moment when a given piece of metallic type suffered some kind of permanent transformation itself seems to speak to a heightened alertness to wartime trauma. ${ }^{8}$ The massive inventory of 615 distinctive types appearing over 13,000 times across the First Folio reads like a catalogue of wounded warriors.

Whatever its conscious and unconscious influences, Hinman's investigation of broken type in Shakespeare's First Folio was among studies that gave analytic bibliographers the immanent sense that they were on the precipice of an important breakthrough. As one scholar prophesied in 1966, "bibliographers and textual critics who want to know how their books were printed will have to search out broken types as one of the quite routine procedures of bibliographic investigation." Not only did this enthusiasm for analysis of damaged type begin after Sirluck's Areopagitica had been published, but broken type analysis also had difficulty achieving the cascading effects its champions anticipated. The reason was straightforward: searching out and collating examples of broken type was altogether impractical on a large scale. Hinman's method, pioneering though it was, relied on close, detailed observations of every glyph in a printed book and a phalanx of notecards of the kind reproduced in figure 2, which he used to aggregate appearances of distinctive letterforms.

Analytic bibliographers' rigorous standards of scholarly accuracy, meanwhile, created a very high bar and led Hinman and his followers not only to note each occurrence of a damaged $\mathrm{B}$, for instance, but also to confirm such tokens across two or more copies. ${ }^{10}$ The labor was intense. As Hinman described the process, 


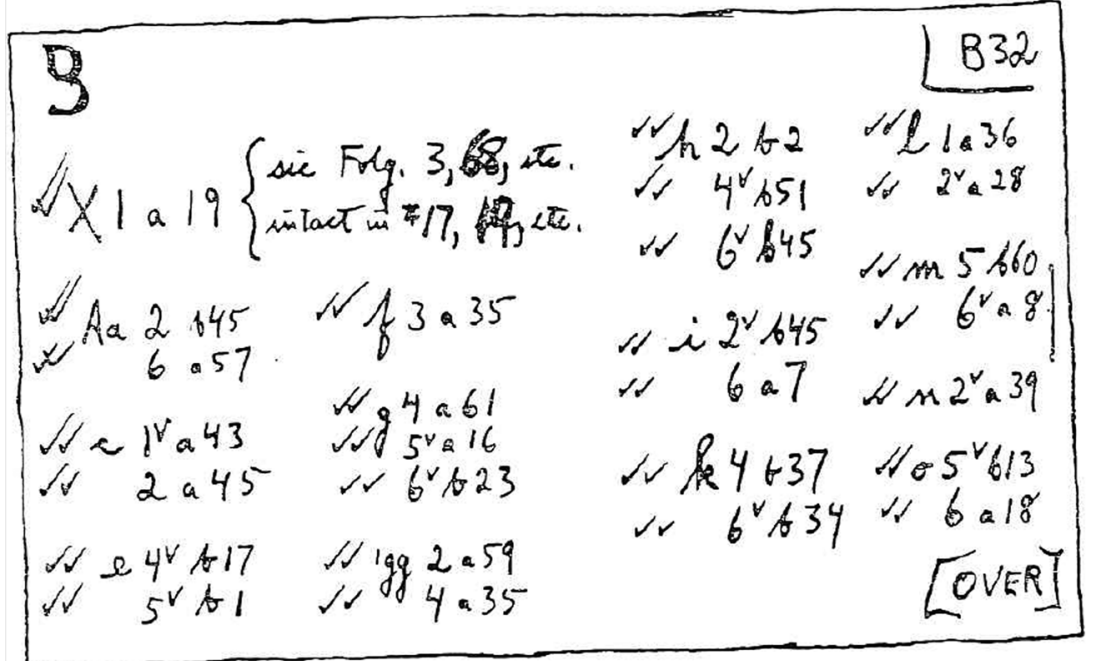

Figure 2 Hinman notecard, reproduced in Charlton Hinman, The Printing and Proof-reading of the First Folio of Shakespeare, r:68.

The copies of the Folio were examined simultaneously, under slight magnification, with the aid of the same machine used to study press variants. At the first appearance of any type that seemed sufficiently distinctive to be recognized consistently, given reasonable alertness and care, a card was prepared. An enlarged freehand drawing of the type was made in the upper left corner of this card, the position of the initial appearance of the type was recorded, and subsequent appearances were entered as they were observed.... This process of accumulating evidence was twice repeated (about six months being required for each survey). ${ }^{11}$

Hinman's results, in other words, required him to spend I8 months staring at the individual letters of a single edition. Widening the scope of such a method beyond an edition, work, or individual author would have increased the time and labor required by many orders of magnitude. This is what makes painstaking recent work by David Adams and David Como so impressive, for both Adams and Como have used damaged type to uncover hidden connections among seventeenth-century radicals and their printers. ${ }^{12}$ Aided by the emergence of digital photography and newly permissive library photographing policies, Adams and 
Como have shed new light on the secret presses of I640s and helped us better understand the material and political contexts of key tracts such as England's Birth-Right Justified, the second edition of Walwyn's The Compassionate Samaritane and the second, enlarged edition of Milton's The Doctrine and Discipline of Divorce.

\section{Who Printed Areopagitica?}

Enter Areopagitica. The new evidence for Matthew Simmons's role in printing Areopagitica is substantial. A minimum of four damaged and distinctive characters that appear in Areopagitica also appear in Simmons's acknowledged works. It has long been thought possible that Simmons (I608[?]-I654) "may have had a hand" in Areopagitica, as Ian Gadd puts it. ${ }^{13}$ In a 2015 conference paper at the Modern Language Association's annual convention, Nicholas von Maltzhan argued that Areopagitica's watermarks are consistent with other imprints by Simmons. ${ }^{14}$ Yet Simmons has been but one of several plausible candidates and, according to renowned Milton bibliographer John Shawcross, "the only reason [people think that Simmons printed Areopagitica] is that he printed most of Milton's works in I643-1649." According to Shawcross, however, "The type and devices are not similar to those in other books from his press, and the accidentals are significantly different from those, say, in either division of Tetra[chordon]." ${ }^{15}$ Instead, Shawcross attributed Areopagitica's printing to Augustine Matthewes, with whom it had long been assumed Milton had an established relationship. ${ }^{16}$ Shawcross followed William Riley Parker in crediting Matthewes for Milton's also anonymously printed $A$ Maske (1637) and then adduced evidence from a second anonymously printed publication, Epitaphium Damonis, to suggest that Matthewes was responsible for all three texts-A Mask, Epitaphium Damonis, and Areopagitica. But even Parker, whose 1936 article forms the foundation for this line of thinking, acknowledged that "we cannot answer the question [of $A$ Mask's printer] positively." He could only go so far as to say that Matthewes "most probably" printed the drama. ${ }^{17}$ It is thus worth reiterating that no known Miltonic publication bears Matthewes's name or initials. Since Shawcross's argument for Areopagitica's printer relied on the ascriptions of two other anonymous publications, the risk of compounding errors has always been acute. 
There have been other candidates besides Simmons and Matthewes. Over the course of his career, Milton worked with at least ro different print houses. ${ }^{18}$ Milton had entrusted at least two pamphlets to the printer Edward Griffin in the early r640s, and for the expanded second edition of Doctrine and Discipline of Divorce (1644) he turned to the radical pro-parliamentary printer Gregory Dexter. As Como has shown, Dexter's clandestine printing oeuvre included not only Milton's inflammatory divorce tract but also controversial pamphlets by radical separatist Roger Williams and many other heterodox thinkers. We will say more about Dexter in what follows, but there have been other candidates, too. Recent scholarship on the clandestine printing of Milton's Tetrachordon (1645) by Sharon Achinstein and Benjamin Burton has raised the possibility of a printers' network in this period that also included Thomas Paine and Francis Neile. ${ }^{19}$ Ruth Raworth, the printer of Milton's 1645 Poems, is another candidate.

Simmons, however, had printed two other Miltonic tracts in the same period, the first edition of Doctrine and Discipline of Divorce (with Thomas Paine) in I643 and Milton's Judgment of Martin Bucer (I644). Somewhat notorious for unlicensed printing, Simmons would also go on to print Milton's Tenure of Kings and Magistrates (1649) and Eikonoklastes (I649). After Matthew Simmons's son Samuel inherited the printing business from his widowed mother, Mary, Samuel would contract with Milton to print Paradise Lost. ${ }^{20}$ It would almost seem odd if Matthew Simmons had not printed Areopagitica. Yet circumstantial evidence has pointed in other directions, and hard evidence has been challenging to find.

Areopagitica's design suggests an understandable attempt to cloak the printer, for it included none of the decorative woodblock initials or factotums that often introduce sections of early modern books. One of a clutch of "heavily anonymized" defenses of toleration and the free press published in mid- to late 1644, Areopagitica has been called "indistinguishable from thousands of other unassuming print publications." ${ }^{21}$ While it is true that not every printer possessed the Greek type used for Areopagitica's Euripides quotation, typography expert Derek Nuttall writes that the italic titling font in which Milton's name appears on Areopagitica's cover was "used by virtually every printer in England throughout the seventeenth century." 2 Areopagitica's printer allowed himself only a single bit of flair-a row of crowned-harp fleurons at the head of the tract. The added risk of including these, however, has proven defensible by time. Neither a parliamentary 
committee scrutinizing Milton's pamphlets in December I644 nor modern scholars armed with library collections and finding aids have convincingly matched the relatively common crowned harps to a known printer.

Yet, as Hinman demonstrated, individual pieces of metallic type were damaged or worn in distinctive ways, and these kinds of fingerprints were practically impossible to mask. Few if any readers consciously think of letterpress books in this way, but each page of Areopagitica required an average of 240 lowercase e's and 3.7 uppercase C's. Composed in formes of four pages, each forme, then, required about 900 individual e's and 15 individual C's (plus roughly 585 a's, 505 h's, I35 b's, and so forth). ${ }^{23}$ In the midst of a print run, piece-by-piece examination of individual type pieces would have been costly and impractical. Any attempt to sift out distinctive specimens, improbable in any scenario, would only have become more challenging with a publication of any length.

Damaged type is thus some of the most reliable evidence for identifying clandestine printers, but precisely because there are so many type pieces involved, such evidence has been very difficult to compile. Manual comparisons of printed characters have indeed been used in Hinman's wake to infer printers responsible for early modern books, yet such studies have been far fewer than a 1960s bibliographer might have expected. ${ }^{24}$ In 1990 Adrian Weiss still felt the need "to lay a foundation for future work leading to the 'precise identification' of fonts by reference to Elizabethan books and printers' fonts." 25

It only slightly overstates things to say the state of bibliographic sleuthing today remains much the same as it was with Hinman and Weiss: high costs of time and effort for uncertain rewards. Scholarly discoveries in the field, such as evidence of books printed in multiple print shops and new identifications of anonymous printers, have mostly depended on a difficult-to-reproduce alchemy of Herculean human labor and good fortune. ${ }^{26}$

Computers and scans from Early English Books Online (EEBO), however, have aided the process by allowing us to identify and aggregate most examples of a given character from Areopagitica. ${ }^{27}$ In early modern literary studies, we often say we value new ways of looking at old texts, but here we mean that literally. Figures $3 \mathrm{a}-\mathrm{b}$ show all (or most) examples of selected majuscule body characters from Areopagitica. We created similar montages for every other body character in Areopagitica (excepting ligatures). Close inspection of these montages forms the basis for what follows. 


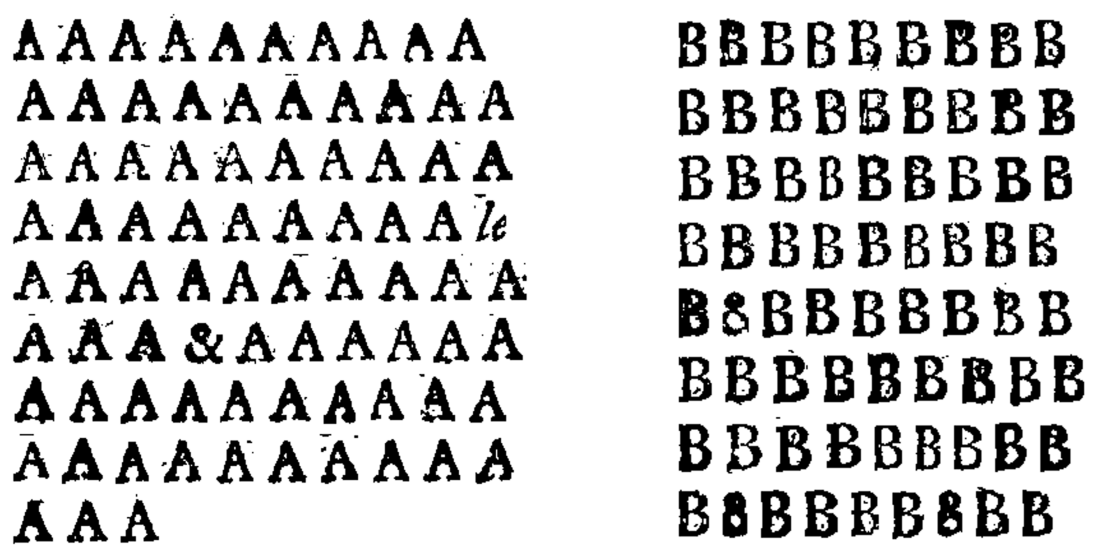

Figures 3A AND 3в Glyphs labeled by Ocular as majuscule A's and B's from Areopagitica (1644).

\section{Optical Character Recognition for EEBO Books}

Since Milton "recognized the essential role that the printing press would play in promoting change and demonstrated the utility of this new technology for the English people," a few words on the technical aspects of our own approach are probably in order. ${ }^{28}$ To extract and aggregate individual characters from EEBO images, we used a state-of-the-art optical character recognition (OCR) tool called Ocular, which-like almost all OCR tools-was initially developed to transform pixelated images into machine-readable text. ${ }^{29}$ Ocular, however, takes into account variables that are distinct to letterpress-era books such as variations in inking level, character appearance, and shifting baselines, and learns general features and variations of a book's font based only on the printed characters in that book. Ocular can also be trained on a language corpus such as Early English Books Online-Text Creation Partnership (EEBO-TCP), thus leveraging the general tendencies of early modern English orthography to help identify letters. This OCR tool translates each line's pixels into the sequence of characters that appears most plausible under the combined model of font variation and early modern language usage. While Ocular achieves a very high success rate overall, some of its "errors, known, read, and collated, are of main service \& assistance toward the speedy attainment of what is truest," as Milton might put it (YP 2:513). Figure $3 \mathrm{a}-\mathrm{b}$ can be instructive in this regard. Since Ocular estimates a book's font without human intervention, it remains occasionally prone to misinterpreting superficially similar clusters 
of pixels such as B and 8. But for the broader purpose of aggregating most if not all tokens of a given sort of type, Ocular is a marvelous aid. Beyond identifying characters, its font models and image coordinates, in particular, helped us automatically segment the EEBO page scans into letters-and, crucially, helped us know where on the digital facsimiles different letterforms could be found.

In the case of Areopagitica, this process left us with roughly 50,000 glyphs sorted (as in fig. $3 \mathrm{a}-\mathrm{b}$ ) by probable character. From these, we identified the 82 impressions-some quite obviously impressions from the same pieces of physical type-that we thought likeliest to help us better understand the pamphlet's printing (see fig. 4). Each impression in some way varies from the others of the same sort, whether because of unusual bends, chipped serifs, or some kind of scar.

\section{$A B B C C C C \bar{C} C C$ \\ CACCDDEEEE \\ FFAFF GGGHH \\ HHKAKLLLLL \\ $M M M M A N N$ N N \\ N N N NARSTT \\ TTTTTTATTV}

WW WW W W A P P B B

FIgURE 4 Selected distinctive majuscule characters from Areopagitica. 
By tracking the recurrence of damaged type impressions across gatherings $\mathrm{A}-\mathrm{F}$, and then confirming all instances of damaged types in physical copies, we were able to determine that Areopagitica was composed from a single set of type. As can be seen in the photos from the physical copy (see fig. 5), each gathering can be linked to the others through chains of recurrences. This was an important first discovery, for we were initially unsure just how many print shops were involved in the tract's publication. The distinctive types recurring across all six gatherings virtually eliminated the possibilities that Areopagitica was printed piecemeal, over a longer stretch of time, or in sections, distributed across several printing houses. On its own, the otherwise unlikely event of these damaged characters recurring so frequently across gatherings seems to preclude the possibility that intermittent "job" work interrupted the printing of Areopagitica. For such a relatively brief text, the frequent recurrence of these damaged type impressions suggests type pieces were drawn off the pile and recomposed soon after they had been redistributed. While the pattern is consistent with a practice of "last type in, first type out," it could also suggest a relatively limited supply of type. ${ }^{30}$

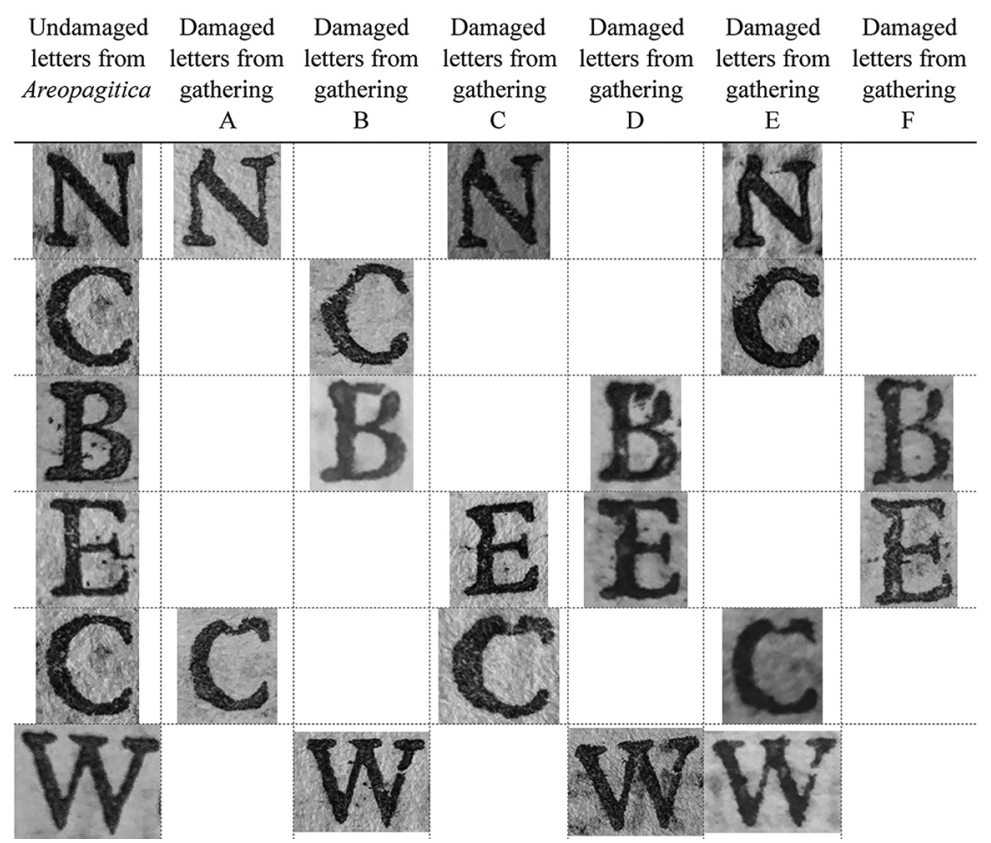

FIGURE 5 Impressions of damaged type that recur across all gatherings (A through F) in Areopagitica (I644). 
In order to compare Areopagitica's distinctive letters against characters from other publications, we selected 85 publications printed by Simmons, Matthewes, Dexter, Paine, Griffin, Neile, and Raworth, as well as I5 anonymously printed tracts, including Milton's A Mask, Epitaphium Damonis, Tetrachordon, and anonymously printed tracts recently ascribed to the radical printers Peter Cole and Richard Overton. From these roo tracts, sourced from EEBO, we extracted and classified more than to million impressions of type. Comparison at this scale introduces many new challenges, including information from the material artifact lost in microfilm digitization and image processing. But the benefit, of course, is unparalleled traction on the question of clandestine printing.

An important clue came when we discovered that whoever printed Areopagitica also had a hand in Tetrachordon and Colasterion. We also learned that several pieces of type from Doctrine and Discipline of Divorce's first edition, printed by Paine and Simmons, appear in Areopagitica. Some of these same pieces, as we shall see, also appear in the group of anonymously printed 1644 tolerationist tracts that includes Roger Williams's The Bloudy Tenent of Persecution, Walwyn's The Compassionate Samaritane (both first editions), and two tracts attributed to Henry Robinson: Liberty of Conscience, and John the Baptist. Since Paine and Simmons had printed the first edition of Doctrine and Discipline of Divorce, we concluded that Areopagitica was part of a much larger clandestine printing operation that involved either Matthew Simmons or Thomas Paine or both. To determine the printer(s) of Areopagitica, meanwhile, was also to identify printers responsible for Tetrachordon and Colasterion.

If another challenge we faced in trying to untangle the printing history of these pamphlets is the sheer volume of characters-especially lowercase characters (see appendix A)—it turns out that Roman majuscule letters alone give nearly sufficient evidence to attribute Areopagitica's printing at least partly to Simmons. Statistical similarity ranking and intensive manual inspection helped us puzzle through slight differences in inking and wear as well as different scaling introduced by the microfilm and digitization processes. We soon saw enough similarities in features from Simmons's acknowledged printing to say that Areopagitica was 
printed with Simmons's type. We confirmed this finding by securing and inspecting multiple close-up digital photographs of physical copies (fig. 6). Distinctive features of Simmons's damaged type include the inked chad that intrudes on the upper bowl of a B, the dented stress of a $\mathrm{C}$, the bent tail of an $\mathrm{R}$ that descends below the baseline, and the fourth diagonal stroke of a W, which is snipped in two. ${ }^{31}$ While any of these on their own could in theory be a false match, our ascriptions to Simmons do not rely on any single match but on the overall preponderance of evidence. As can be observed in Simmons's other known imprints—see, for example, John Cotton's The keyes of the kingdom of heaven, and power thereof and The Way of the churches of Christ in New-England-Simmons owned and used Greek type such as that used for the Euripides quotation on the title page of Areopagitica. ${ }^{32}$

Undamaged letters from Damaged letters from Damaged letters from Areopagitica Areopagitica works printed by Matthew Simmons, 1644-1645

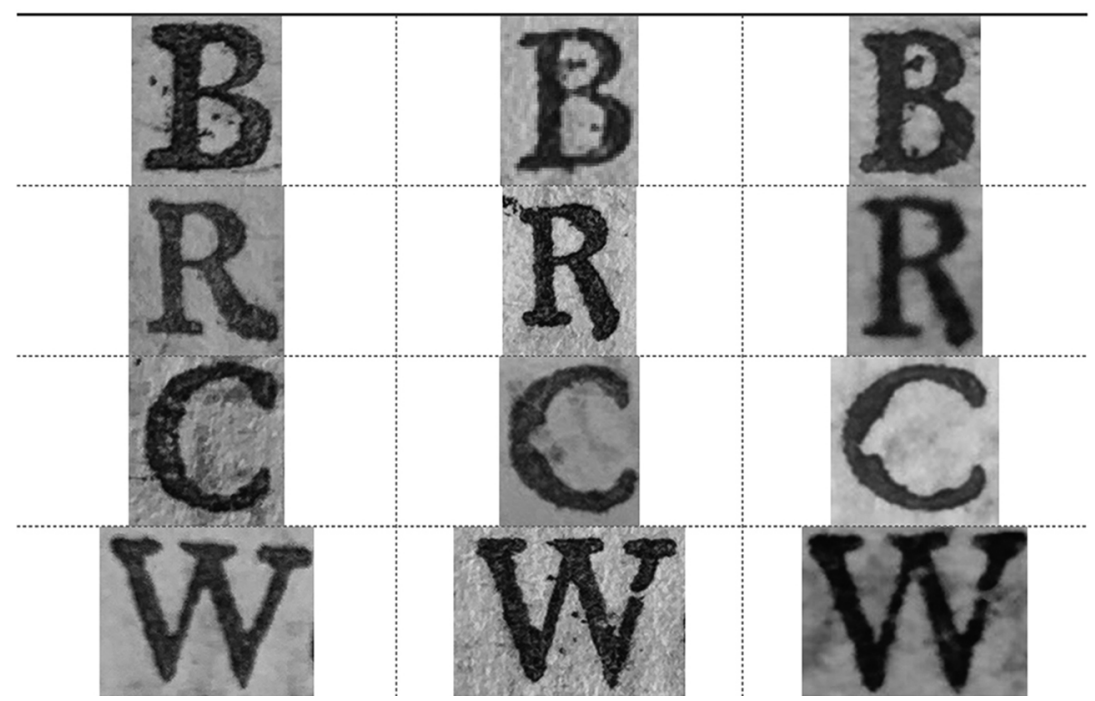

FIgUR E 6 Impressions of damaged type from Areopagitica (I644) compared to contemporaneous impressions from the press of Matthew Simmons. 


\section{Mattherw Simmons}

To add to the typographic evidence, Simmons's connections to illicit printing in late 1644 further suggest both the motive and the means to print Areopagitica. Some of those connections involve Milton himself. Simmons was freed into the Stationers' Company in 1632, but by 1641 he had already developed a reputation for illegal printing with his partner, Thomas Paine, with whom he shared an imprint until early $1644 .{ }^{33}$ Well before he and Paine caused an uproar by printing the unlicensed first edition of Doctrine and Discipline of Divorce in August 1643, Simmons had already spent time in the Fleet for illegal printing. ${ }^{34}$ After his imprisonment, Simmons certainly printed some materials above board. He entered $\mathrm{I}_{3}$ items into the Stationers' Register in 1644 , but he appears again in official records in late 1644, shortly after the appearance of Areopagitica, when Hezekiah Woodward, summoned to Parliament alongside Milton for illegal publications, confessed that he had sought out "a printer named Symons, living near Aldersgate" to print Woodward's Inquiries into the Causes of Our Miseries, an Independent tract with noted echoes of Milton's own. ${ }^{35}$ Woodward, an educationalist whose ties to the Hartlib and Comenius circles put him in much the same intellectual company as Milton during the period when he wrote Of Education, compared censorship to premature conviction much as Milton had done. Likewise, Woodward positioned his own book as the lifeblood of a master spirit; he averred, "truly my spirit could never go forth with any other way of licensing, or widwif'ing such births as are books into the world; surely no better hand to officiate there, than what Truth and Reason affords me."36 Simmons, Woodward, and Milton, therefore, help compose an ideological network of spirits built around reason, toleration, and liberty of the press. Nor were Simmons's potential rewards exclusively political. The Woodward notice discloses that he paid Simmons 55s to print Inquiries into the Causesraising the possibility that Simmons was similarly compensated for his risk in printing Areopagitica. ${ }^{37}$ Milton, too, lived in Aldersgate Street.

\section{Thomas Paine}

Given the strength of the evidence for Matthew Simmons, it would be easy to attribute Areopagitica to Simmons alone. After all, as we have seen, Areopagitica was printed from a single case of type. Yet a few puzzles remain. For example, it is unclear whether Simmons possessed crowned harp fleurons of the kind that appear at the head of Areopagitica (A2r). More significantly, there is strong evidence that another printer, Thomas Paine, 
was involved as well. And if it seems surprising to find type associated with two printers in a tract demonstrably printed from a single case, the chronology makes it doubly so. While Paine and Simmons worked together for many years, their last known collaboration was in February r644- roughly io months before the appearance of Areopagitica - when the pair printed Hezekiah Woodward's A Dialogue, Arguing that Arch-bishops, Bishops, Curates, Neuters, are to be Cut-off by the Law of God. It has long been thought that the Paine-Simmons partnership had already dissolved well before Areopagitica was printed.

Yet in addition to the distinctive letters traceable to Simmons in Areopagitica, there appear four damaged majuscule letters found in works with Paine's solo imprint from both before and after Areopagitica (fig. 7). These works are Quatermayns Conquest (I642), A Dry Rod Blooming (May 1644), An Answer to W.R. (July 1644), and The City-Remonstrance Remonstrated (May 1646). According to the chronology provided by the Thomason Tracts, An Answer to W. R., where figure 7's B appears, is in fact the last published work to which Paine put his name prior to Areopagitica. ${ }^{38}$ Of further note in figure 7 are both the dramatic trough in the stress of the $\mathrm{C}$, which nearly splits the character in half, and the dented stem of the $\mathrm{D}$, a character that by 1646 had evidently suffered additional damage to its upper serif. Unlike Simmons, in whose works we could find no examples of the Areopagitica-style crowned harps, Paine most certainly had crowned harps in his type case as early as $1640 .{ }^{39} \mathrm{He}$ also owned borders and ornamental capitals that would appear in other anonymously printed works by Milton from the period. ${ }^{40}$ Paine's ornamental I that appears in An Answer to W. R. is used again in Tetrachordon in March $1645 .{ }^{41}$ If Paine printed Tetrachordon, it follows that Paine also printed Areopagitica.

This connection is strengthened by an additional anonymously printed pamphlet from sometime in 1644 entitled Divinity and Philosophy dissected and set forth by a mad man. While Divinity and Philosophy gives an Amsterdam imprint, it shares several distinctive letters with both Areopagitica and Paine's acknowledged works. ${ }^{42}$ One of Paine's most characteristic design features is an arabesque border built up from two rows of interlocking tiles. Its presence in Divinity and Philosophy strongly suggests the tract was produced by Paine. Someone involved in Divinity and Philosophy was also involved in Areopagitica, and here that person was almost certainly Thomas Paine.

Like Matthew Simmons, Paine was responsible for many of the most radical Parliamentarian tracts of the mid-I640s. Paine had been freed of the 


$\begin{array}{cccc}\text { Undamaged } & \text { Damaged letters } & \text { Damaged letters } & \text { Damaged letters } \\ \text { letters from } & \text { from } & \text { from Divinity } & \text { from works } \\ \text { Areopagitica } & \text { Areopagitica } & \text { and Philosophy } & \text { printed by } \\ & & \text { Set Forth(1644) } & \text { Thomas Paine, } \\ & & & 1642-1646\end{array}$

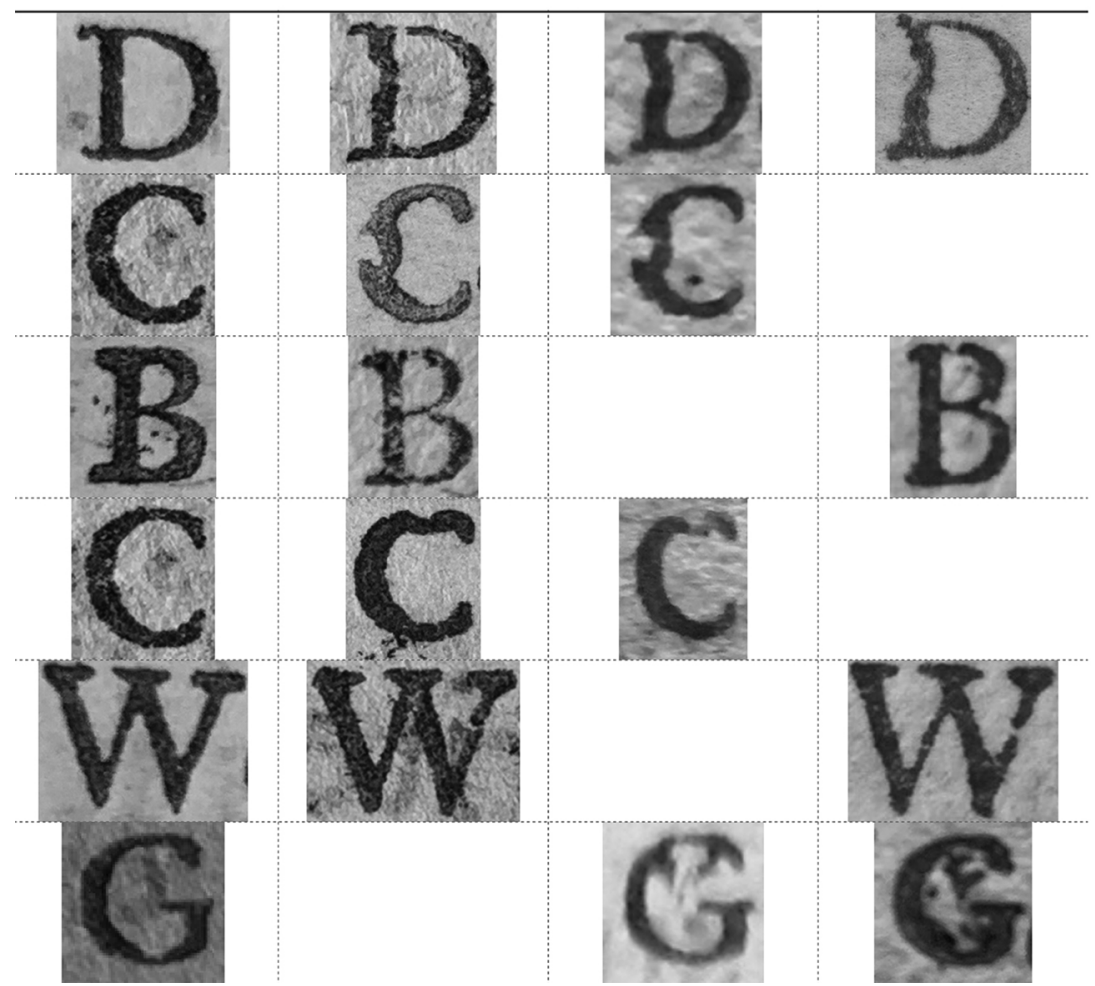

FIGURE 7 Impressions of damaged type from Areopagitica (I644) compared to similar impressions from the press of Thomas Paine, $\mathrm{I}_{42}-46$.

Stationers' Company in 1628 following an apprenticeship with John Dawson the elder, who had also served as master to Simmons. Ultimately, Paine would be employed by the Council of State in the r65os and receive a gratuity for printing pro-parliamentary books. In the interim Paine forged his partnership with Simmons and then became the main printer for radical pamphleteers such as Lady Eleanor Davies and William Walwyn. He was a key figure in a "network of Independent activists in London ... wag[ing] an unauthorized street-level propaganda campaign to counter the Presbyterians." ${ }^{\text {"3 }}$

But how is it that Paine's distinctive letters appear alongside Simmons's when their partnership had apparently dissolved several months earlier? 
Evidence from three separate publications into at least mid-late I644 shows that Paine and Simmons were collaborating well past the putative dissolution of their partnership. An undated fourth publication suggests much the same.

\section{Paine-Simmons: From Shared Imprint to Underground Collaboration}

In particular, an $\mathrm{F}$ with a highly distinctive lower arm appears in both $A$ Dry Rod Blooming (May 1644) and England's Monarch (I644), works that were published with only Paine's name in the imprint (fig. 8). That same $\mathrm{F}$ then subsequently appears in a June work under Simmons's imprint, The Keyes of the Kingdom of Heaven, and then again in Paine's Answer to W.R. (July 27). The story told by the imprints alone of an early i644 PaineSimmons split is thus misleading. It is falsified, we might say, by a flagging F. Likewise, Simmons's W with a severed fourth diagonal appeared much earlier in Paine's Quatermayn's Conquest (1642) and in Simmons's $A n$ Alarme to Awake Church-Sleepers (1644), but moved between Paine's A Dry Rod Blooming (May 1644) and Simmons's Inquiries into the Causes of Our Miseries (December 1644).

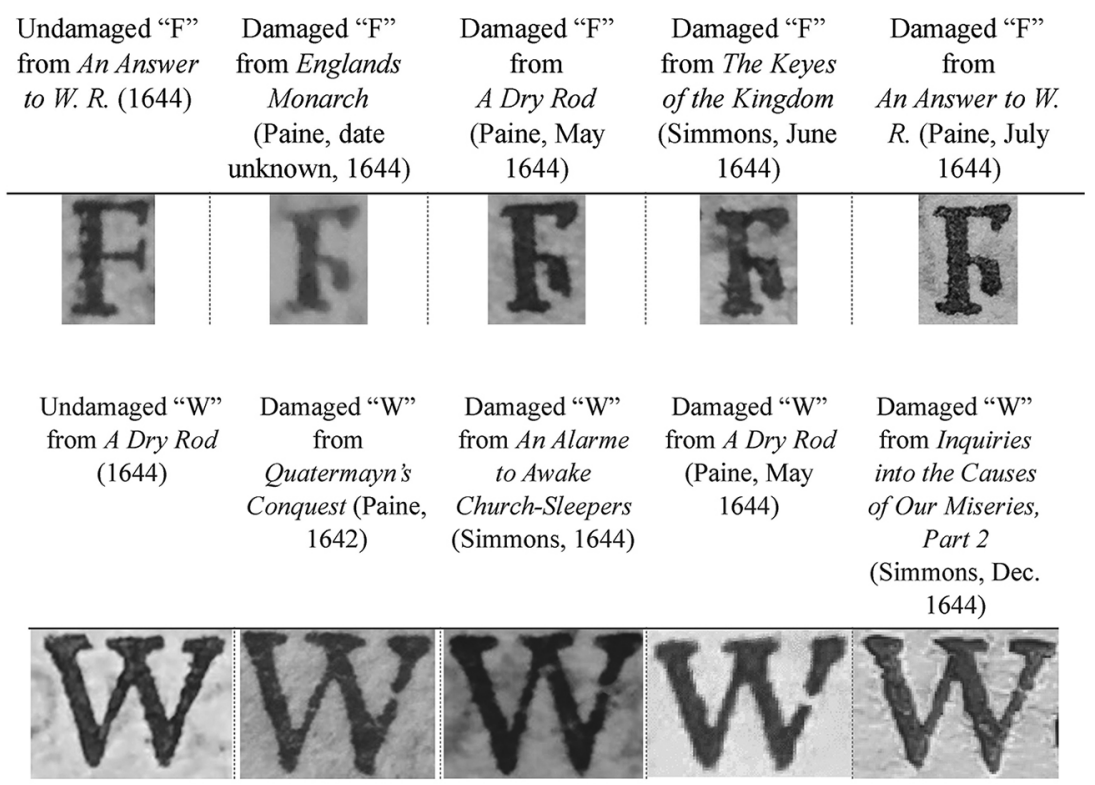

FIGURE 8 AND 9 Impressions of a distinctive $\mathrm{F}$ and $\mathrm{W}$ from the ostensibly solo imprints of Thomas Paine and Matthew Simmons between February and August I644. 
We have seen that both Paine and Simmons had means, motive, and opportunity to print Areopagitica, but what about their method? Here things get a little trickier. A slightly odd pattern of damaged type pieces suggests that there may have existed an illicit set of type to which several printers had access. Just as type pieces from Paine's and Simmons's solo imprints appear in Areopagitica, so do damaged pieces of type from their joint imprints appear in Areopagitica. An L with a beak that dips below the baseline, a $\mathrm{G}$ with a barb that doubles back into the aperture, and a $\mathrm{C}$ with a dented upper stress can each be found in Areopagitica and in Paine and Simmons's collaborative imprints, including God in the Mount and the first edition of Milton's Doctrine and Discipline of Divorce (1643) (fig. Io). At the same time, there are several solo imprints published between February and December 1644 by both Paine and Simmons that share little with Areopagitica. ${ }^{44}$ Such a pattern suggests that Paine and Simmons enjoyed access to a secretive third set of type.

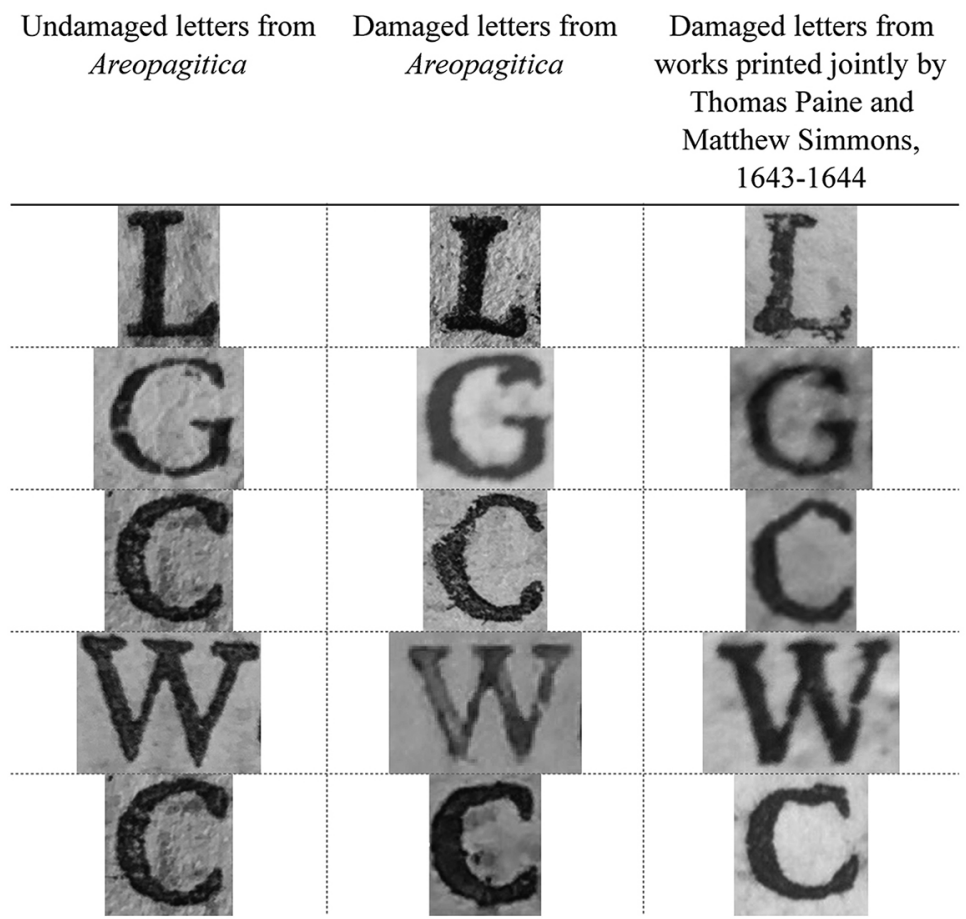

Figure Io Impressions of damaged type from Areopagitica (1644) compared to similar impressions from joint imprints of Thomas Paine and Matthew Simmons, I643-44. 
It is difficult to discern how decisions were made as to which of these sets of type would be used to print different texts. The preservation of anonymity does not seem to have been a determining factor in the selection of one set over another. For example, we have determined that the anonymous printing of Milton's Of Education (1644) was also conducted by Paine and Simmons, but with a set of type that they also used to compose several of their named imprints, including An Answer to W.R. (Paine, 1644) and ADry Rod Blooming (Paine, I644) (fig. II).

\begin{tabular}{ccc}
$\begin{array}{c}\text { Undamaged letters from } \\
\text { Of Education (1644) }\end{array}$ & $\begin{array}{c}\text { Damaged letters from } \\
\text { Of Education (1644) }\end{array}$ & $\begin{array}{c}\text { Damaged letters from } \\
\text { works printed by } \\
\text { Gregory Dexter or } \\
\text { Thomas Paine and/or } \\
\text { Matthew Simmons, } \\
\end{array} \quad 1644$ \\
\hline
\end{tabular}

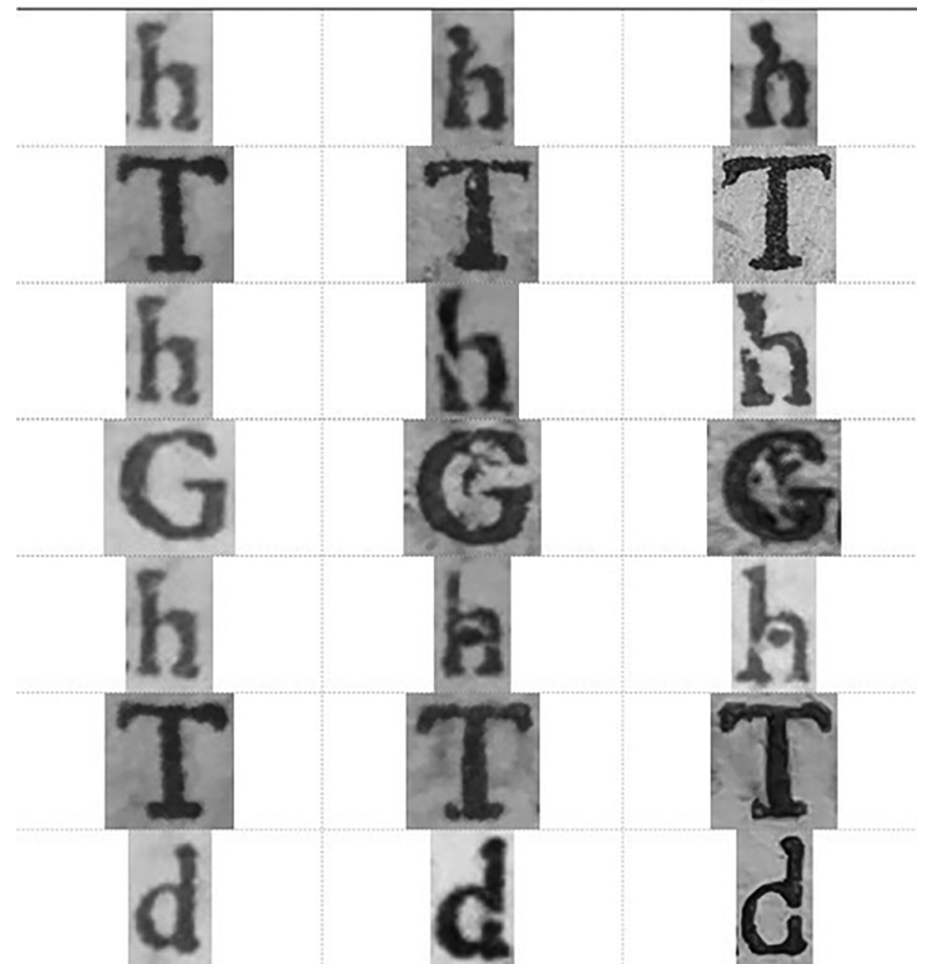

FIGURE II Impressions of damaged type from Of Education (I644) compared to similar impressions from the presses of Thomas Paine and Matthew Simmons, I644. 
While we cannot say exactly why Paine and Simmons selected this or that set of type for a given job, the implication of the cumulative evidence to this point - that there was a third set of type available jointly to Paine and Simmons-raises questions about how such a set emerged. If the type used to print Areopagitica was neither necessarily that of Paine's nor Simmons's solo imprints, but this same type was regularly accessed by both printers, then from where did this shared type come? Typographical evidence suggests enduring effects from an illicit collaboration with yet another player, Gregory Dexter.

\section{Gregory Dexter}

The precise nature of Dexter's role is again difficult to ascertain, but Areopagitica is not simply an example of two printers divvying quires between themselves. The gatherings in which distinctive letter-forms reappear indicate Areopagitica was composed from a single set of type that can be attributed overwhelmingly to both Paine and Simmons, although slightly more type pieces are associated with the former. Yet there are several damaged type impressions that appear in Dexter's acknowledged and unacknowledged publications from the 1640 s that also appear in the joint imprints of Paine and Simmons and that we find again in Areopagitica. This suggests that Dexter's type somehow made its way into the set of type from which Areopagitica was composed (fig. I2).

The appearance of Dexter's type in Areopagitica is difficult to explain, and what makes it especially so is that Dexter's own clandestine printing operation had supposedly been shut down by a raid in February i644, days after he printed the second edition of The Doctrine and Discipline of Divorce. Stationers' Company records even include the company's permission in June 1644, five months before Areopagitica, for Dexter to liquidate his printing equipment. ${ }^{45}$ David Como, who has studied Dexter closely, reports that the raid precipitated Dexter's "permanent exit from the trade." ${ }^{46}$ How then do we explain the continued appearance of damaged type impressions from Dexter's press well after his departure from the trade in imprints by Paine and Simmons? One possibility is that Paine and/or Simmons quietly acquired some of Dexter's type on the black market. There is an intriguing note in the records of the Stationers' Company about unspecified "disobedience" by the printer Peter Cole during the raid on Dexter's press on February 5, 1644. Cole confessed that he "did disobediently Carry [himself] in resistence of the Warden of [his] Company (and those that assisted him), 
Undamaged letters from $A$ Key into the Language of America (Gregory Dexter, 1643)
Damaged letters from works printed by Gregory Dexter, 1642-1644
Damaged letters from works printed jointly by Thomas

Paine and Matthew Simmons, 1642-1644

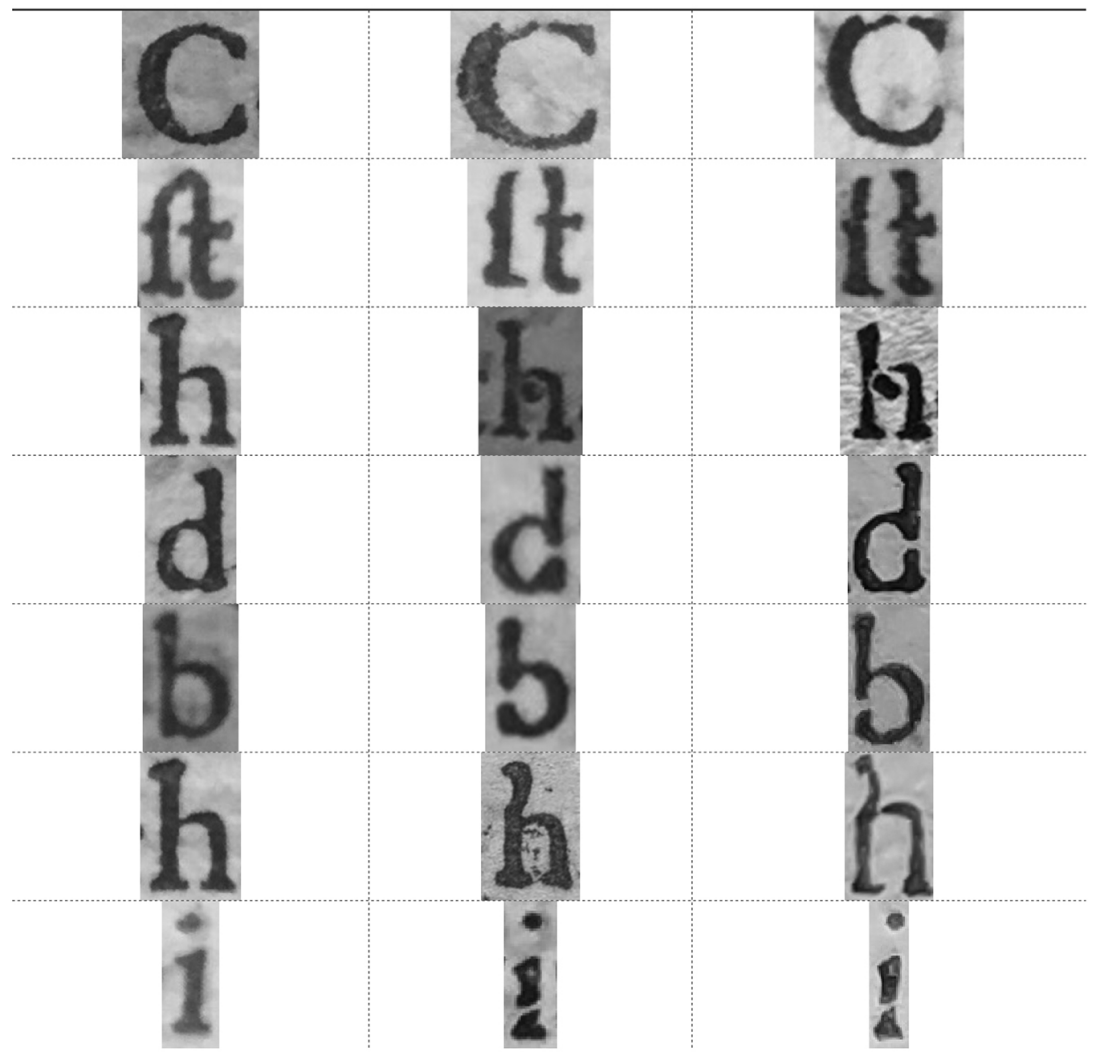

Figure I2 Damaged type impressions from the press of Gregory Dexter, I642-44, compared to similar impressions from the joint imprints of Thomas Paine and Matthew Simmons, $1642-44$.

in a search and taking downe a presse in the house of Gregory Dexter, wherewith was unlawfully printed divers bookes Contrary to a late ordinance of Parliament." ${ }^{\prime 7}$

Cole was another key node in London's radical press network, and the implication that he ultimately got caught aiding Dexter hardly precludes the possibility that Cole also successfully secreted away some of Dexter's type before his "resistance" was discovered. On February 9, four days after the raid of Dexter's premises, the bookseller and collector George Thomason acquired a tract by Roger Williams evidently made with Dexter's 
type. ${ }^{48}$ It may be that this tract had been printed several days earlier. But if Thomason's copy was fresh off the press, like many of the other texts that he collected, it would suggest that at least some of Dexter's type had not been seized.

For printers of unlicensed materials such as Paine and Simmons, meanwhile, it seems reasonable that they might have wished to acquire some cheap type, which would have the advantage of muddying the waters for investigating authorities. In this regard, Cole would have been an altogether plausible conduit. In 1642, while Gregory Dexter was away in the parliamentary army, his wife, Abigail Dexter, had worked with one William White from Dexter's shop to produce King James's Judgement of a King and Tyrant. ${ }^{49} \mathrm{~A}$ distinct possibility is that some combination of Cole, Abigail Dexter, and others in the Dexter shop, having secreted type away from Dexter's premises before the raid concluded, simply distributed it into another font that was available to Paine and Simmons, perhaps the same font we have suggested that they occasionally used for their solo and joint imprints. Already in late February, just a few weeks after the raid on Dexter's press, a distinctive $\mathrm{C}$ with a severed upper terminal and an $\mathrm{ft}$ with a split ligature-both of which were associated previously with Dexterappeared in a joint Paine-Simmons pamphlet, $A$ Tryall of the New-Church Way in New-England (fig. I2). In what follows, we detail how this mutable typeset, with type associated at one time or another with Dexter, Paine, and/or Simmons, links Areopagitica to an even wider expanse of radical tolerationist tracts.

\section{AREOPAGITICA AND RADICAL TOLERATIONISM IN I644}

The damaged type impressions in figures $\mathrm{I} 3$ and $\mathrm{I} 4 \mathrm{not}$ only indicate a direct typographical lineage from Dexter to Paine and Simmons, but also tie a number of additional anonymous imprints from 1644 into what we can now identify as a sophisticated ideological program of clandestine printing executed collaboratively by Paine and Simmons throughout I644. Como writes of a "series of extreme defenses of toleration that appeared in the months after Dexter's business was destroyed ... that ... were produced surreptitiously, without distinctive ornaments, in anonymized editions that thwarted the authorities as surely as they have stymied attempts by modern scholars to identify the printers involved." ${ }^{50}$ Among these tracts were Henry Robinson's Liberty of Conscience in March, Roger Williams's The Bloudy Tenent of Persecution in July, William Walwyn's The Compassionate 
Samaritane (summer), and Robinson's John the Baptist, Forerunner of Christ Jesus; or, A Necessity for Liberty of Conscience in September.

There is some thought that Robinson, himself a wealthy merchant, financed the publication of many of these tracts, and if that is so, the typographical evidence indicates that Paine and Simmons worked the presses. ${ }^{51}$ Another possibility-however unlikely - is that Gregory Dexter was directly involved in printing some or all of the 1644 tolerationist tracts, up to and potentially including Areopagitica. Como argues that Dexter's demise, above all, sparked Milton's thematic turn from episcopacy and divorce to press freedom, and yet Dexter's activities and whereabouts in late I644 remain uncertain. Como observes correctly that no imprint bears Dexter's

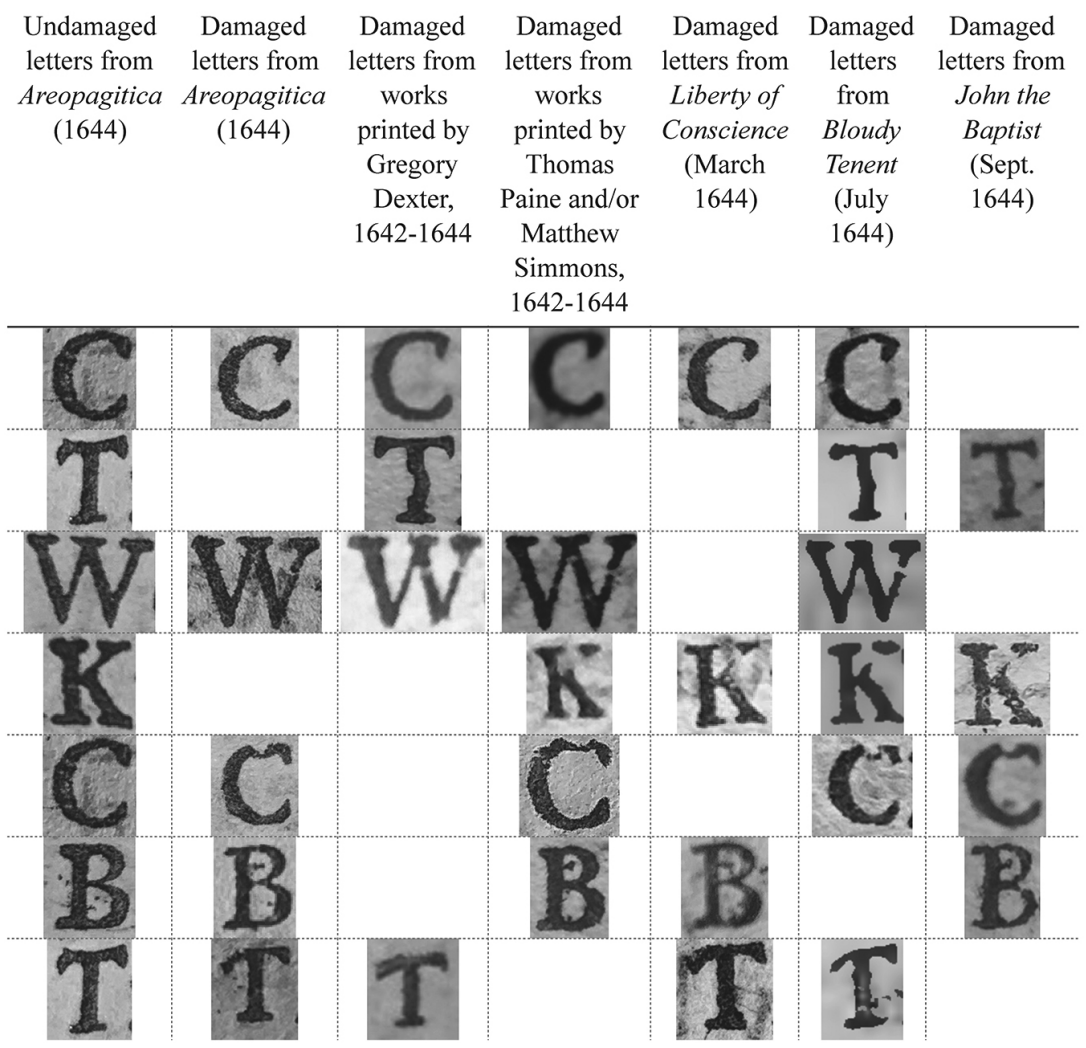

FIGURE I3 Damaged type impressions from the press of Gregory Dexter, I642-44, compared to similar impressions from the joint imprints of Thomas Paine and Matthew Simmons, $1642-44$, and three anonymous imprints from MarchSeptember I644. 

Undamaged letters from Damaged letters from works Damaged letters from The Compassionate Samaritane (1644) printed by Gregory Dexter, Thomas Paine and/or Matthew Simmons, The Compassionate Samaritane (June-July, 1644)

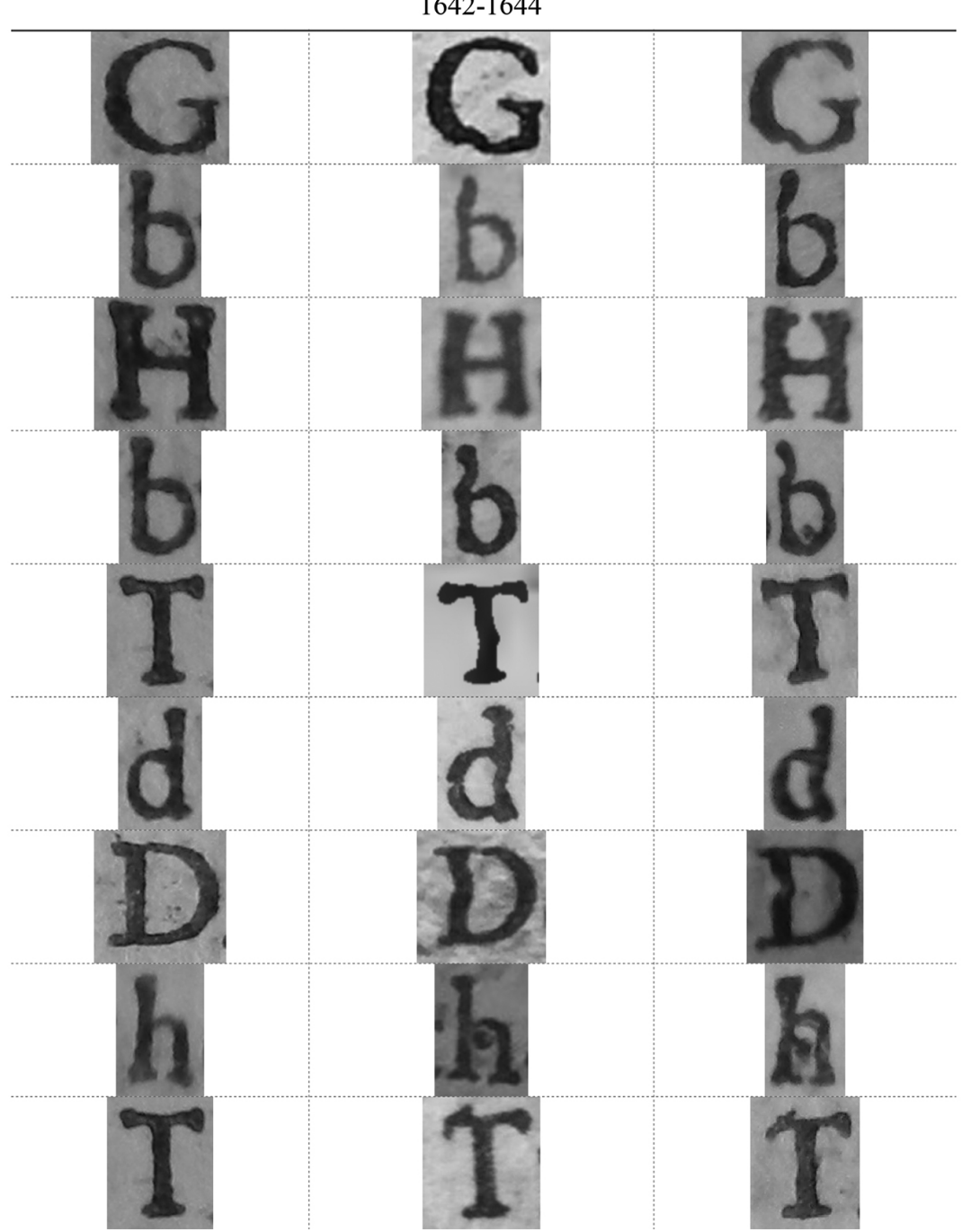

FIGURE I4 Damaged type impressions from the presses of Gregory Dexter, Thomas

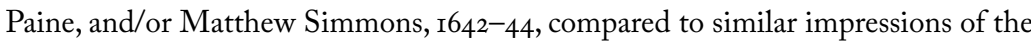
first edition of William Walwyn's The Compassionate Samaritane (June-July I644).

name after the February raid, and Dexter would shortly make his way to Rhode Island, where he took refuge with his friend and ideological comrade, Roger Williams. As Como puts it, “The printer had seen enough: he 
now fled into exile, resettling in Roger Williams's colony of Providence."52 The question is when. Dexter may have traveled when Williams did in September 1644, but this is entirely speculative. It is possible that Dexter was still in London in November 1644 and actively lent some remaining type and/or expertise to the printing of Areopagitica.

Not surprisingly, type once associated with Dexter continues to appear in books and pamphlets well into the mid-r640s. The Stationers' Register includes a petition from the printer Moses Bell to acquire materials seized from Dexter, and many distinctive letters from Dexter's case can be found in Bell's books as of July I644. ${ }^{53}$ Yet the hypothesis that Cole and other workers in Dexter's shop stashed away type away before it could be seized would lead us to expect a kind of forking of Dexter's stock. Such a split would separate type that found its way via Cole to Paine and Simmons, which we call "group A," from type that was purchased by Bell upon Dexter's liquidation, or "group B." One of Bell's imprints, An exact relation of that famous and notable victorie obtained at Milford-Haven, from July 25, I644, shows just such a dispersion (fig. I5). None of this book's damaged type impressions, which are listed in group B (fig. 15 ), appear in the 24 acknowledged imprints of Paine or Simmons (or Cole) that we examined dating from February I644 to I649. Some of Dexter's type-the group we're calling group B-had nothing to do with Areopagitica.

By contrast, several of the damaged type impressions in group B are in fact present together with impressions from group A in Paine' and Simmons's collaborative imprints that date from before the raid in February 1644 . The $\mathrm{g}$ with a divided stress and disconnected loop in figure I5, for example, is present in both the first and second editions of Milton's Doctrine and Discipline of Divorce, the former printed jointly by Paine and Simmons around August I, I643, and the latter by Dexter around February 2, $1644 \cdot{ }^{54}$ While the trajectory of group B is beyond the scope of this article, dead-ending for our purposes in Bell's possession, the letters of group A, as will presently be shown, would find their way into still more clandestine enterprises undertaken by Milton, Paine, and Simmons.

Areopagitica was followed in March I645 by the simultaneous and also anonymously printed Tetrachordon and Colasterion. The identities of the printers of these tracts had likewise eluded scholars for decades until recent work by Sharon Achinstein and Benjamin Burton, which points to Paine, Simmons, or both. ${ }^{55}$ While Achinstein and Burton note Parker's I937 hypothesis that Paine was involved in the printing of Tetrachordon on the basis of a number of printers' devices and ornamental capitals that the text shared with Paine's earlier imprints, they understandably refrain from 


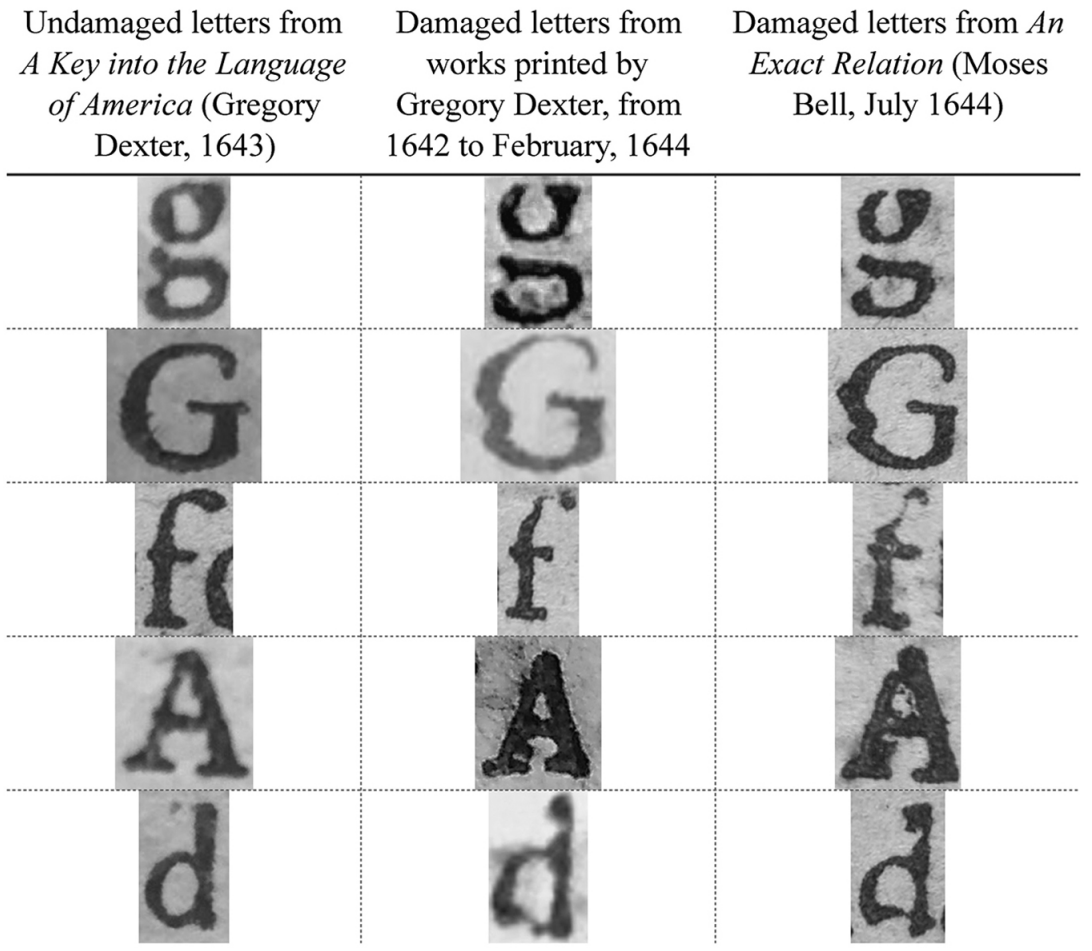

Figure I5 Dexter Type Group B. Damaged type impressions from the press of Gregory Dexter to February I644, compared to similar impressions from An Exact Relation, printed by Moses Bell in July I644.

declaring a Paine-Simmons collaboration because (a) the Paine-Simmons partnership had officially dissolved well before these tracts, and (b) the tracts' devices were strongly associated with Paine in I645 and only with Simmons later, in 1646. Yet further typographical evidence suggests that most of Tetrachordon's signatures were composed from the same set of type used to print several radical, tolerationist tracts, including Areopagitica-a set of type once strongly associated with Dexter to which Paine and Simmons also turned through 1644 and into 1645 .

The damaged type impressions in figure i6 establish explicit links between the type in Tetrachordon and several imprints from group A, including Dexter's far earlier edition of Milton's Of Prelatical Episcopacy (July I64I), Paine's and Simmons's An Argument or, Debate in Law (September I642) and The Doctrine and Discipline of Divorce (August I643), and Paine's A Dry Rod Blooming (May i644). 


$\begin{array}{cccc}\begin{array}{c}\text { Undamaged letters } \\ \text { from Tetrachordon }\end{array} & \begin{array}{c}\text { Damaged letters from } \\ \text { Tetrachordon (1645) }\end{array} & \begin{array}{c}\text { Damaged letters from } \\ \text { works printed by } \\ \text { Gregory Dexter, } \\ \text { Thomas Paine and/or } \\ \text { Matthew Simmons, }\end{array} & \begin{array}{c}\text { Damaged letters } \\ \text { from works printed } \\ \text { by Francis Neile, }\end{array} \\ & & \text { 1644-1645 }\end{array}$
$1642-1644$

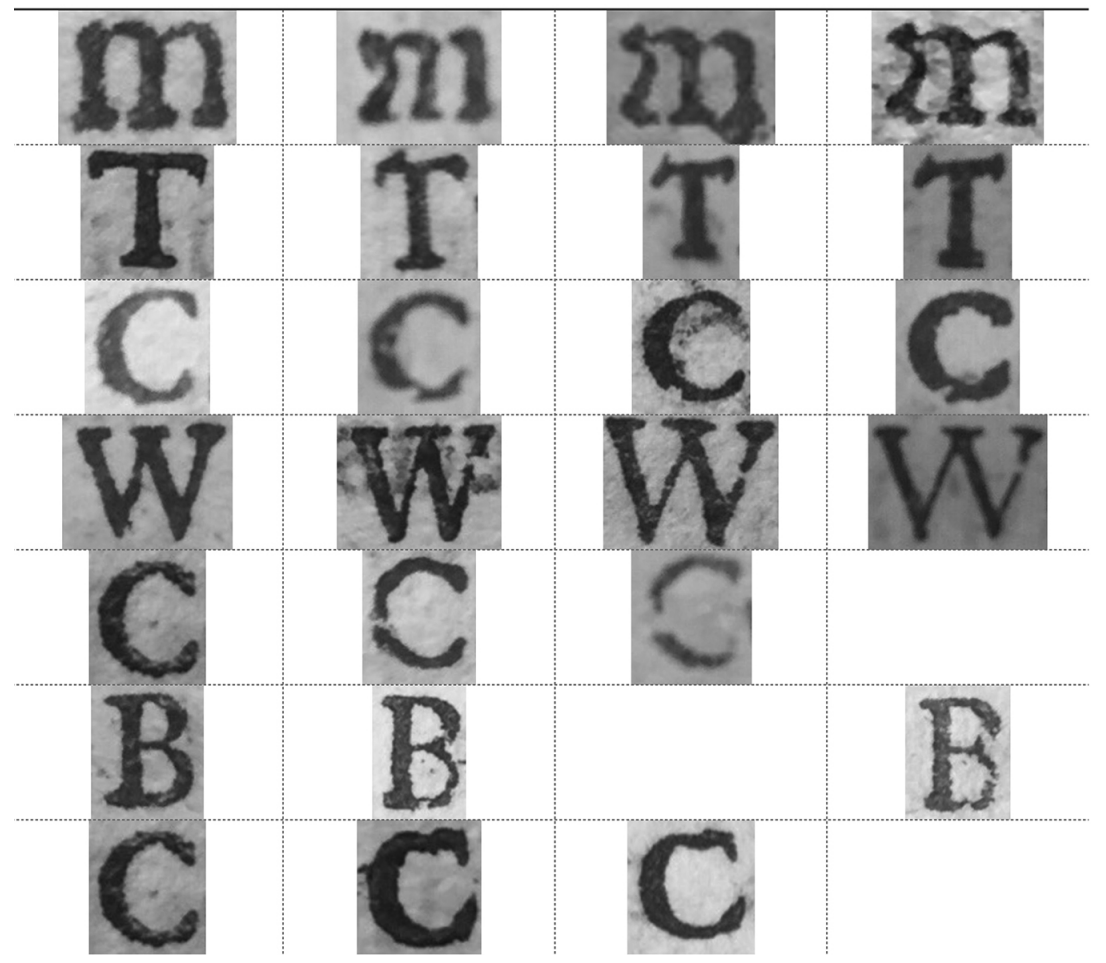

Figure i6 Damaged type impressions from Tetrachordon (I645) compared to similar impressions from the presses of Dexter, Paine, and Simmons, I642-44, and from works printed by Francis Neile, 1644-45.

Figure I6 also includes typographical evidence from the London printer Francis Neile, for whom at least some account is necessary. Historians of the book trade have asserted that Neile formed some kind of printing partnership with Matthew Simmons, perhaps as early as $1644 .^{56}$ While surviving details of this relationship are scant, Tetrachordon's typographical evidence might be thought to suggest Neile's earlier involvement in Areopagitica. However, despite the damaged type impressions that appear in both Tetrachordon and Neile's imprints, the total evidence actually works against the possibility of Neile's involvement in Areopagitica, or for that matter, in any of the anonymous imprints in group A dating from I644. The 
first occurrences we have located in Neile's acknowledged work for the $m$ with a severely dented left stem, the $\mathrm{C}$ with a chipped lower stress, and the W with a snipped fourth diagonal date to August 5, 1645, in Israel's Prayer in Time of Trouble, nearly five months exactly after Thomason acquired his Tetrachordon copy. Moreover, Neile's imprint with the strongest links to group A did not appear until October 28, 1646, nearly two years after Areopagitica and Tetrachordon, in A Shadow of the Victory of Christ (fig. I7).

Given that the connections to Neile appear to be so much stronger after I644, it is most likely that Neile ended up with type once used by Paine and Simmons through his later partnership with Simmons instead of through his involvement with Paine and Simmons's clandestine printing operations

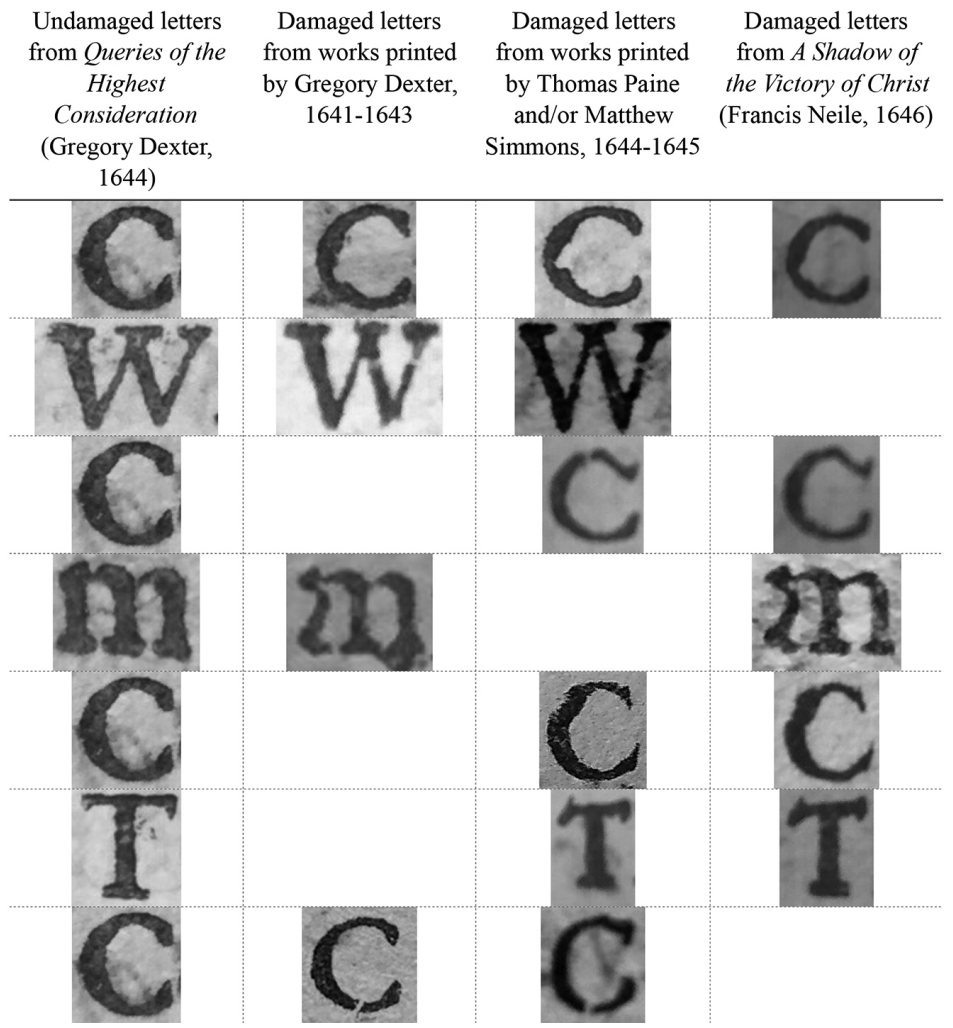

FIGURE I7 Damaged type impressions from the press of Gregory Dexter, I64I-43, compared to similar impressions from the presses of Thomas Paine and/or Matthew Simmons as well as from A Shadow of the Victory of Christ, printed by Francis Neile on or around October 28, I646. 
in 1644-45. In other words, rather than linking Neile backwards in timeto Dexter's raided press and Paine and Simmons's anonymous imprints of 1644-45-these damaged type impressions anticipate Neile's subsequent introduction into the wider Simmons-Paine orbit.

The final Miltonic tract to consider is Colasterion, which has long been suspected of a close association with Tetrachordon, not only because of their common authorship but also because of thematic similarities and their simultaneous publication on or around March 4, I645. The chain of damaged type impressions from the presses of Paine and Simmons, from Areopagitica, and from Tetrachordon, supports the connection between these texts (fig. 18). With the inclusion of Colasterion, we ultimately ascribe nine new tracts, Areopagitica, Of Education, Tetrachordon, Colasterion, John the Baptist, Bloudy Tenent of Persecution, Divinity and Philosophy, The Compassionate Samaritane, and Liberty of Conscience, in whole or in part to Thomas Paine and Matthew Simmons.

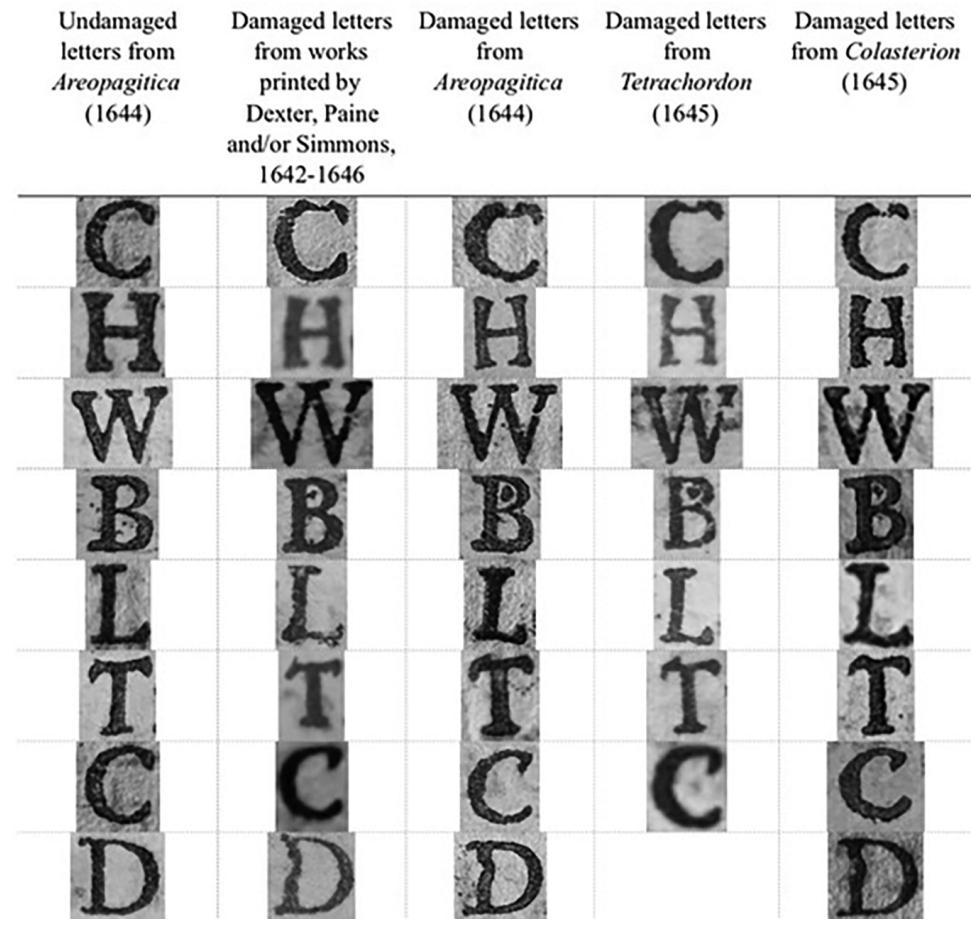

FIGURE I8 Damaged type impressions from the presses of Gregory Dexter, Thomas Paine, and/or Matthew Simmons, 1642-46, compared to similar impressions from Areopagitica (I644), Tetrachordon, and Colasterion (I645). 


\section{CONCLUSION}

From the perspective afforded only by title pages, Paine and Simmons had stopped collaborating by February 26, i644. The evidence from damaged and distinctive type, by contrast, shows that they continued to work together and produced Milton's Areopagitica in November as well as printing some of the most significant tolerationist tracts of the mid-seventeenth century. Despite the efforts of parliamentary authorities and proxies of the Stationers' Company, the radical press of the early I640s that had produced Milton's Doctrine and Discipline of Divorce and early works by Roger Williams was not extinguished with the raid on Gregory Dexter's shop. The ideological mantle, and even some of the printing materials, passed on to Paine and Simmons. By the time of the raid on Dexter's press, Paine and Simmons had already achieved a strong partnership. They printed daring sectarian and pro-parliamentary books and pamphlets, but soon after the raid on Dexter, they took their partnership underground. This collaboration was so well cloaked that it has taken more than three centuries to identify convincingly their various publications.

Yet, if the evidence of damaged type sheds light on many mysteries, questions also remain. For example, what role, if any, did Gregory Dexter play in 1644 in the publication of other tolerationist tracts? How was this broader campaign of toleration organized and financed? Which other tracts not studied here fell into this larger Independent movement for radical toleration? How did the printers of these tracts navigate internal tensions among tolerationist authors such as those between Williams's general toleration and Milton's version limited to "brotherly dissimilitudes"? ${ }^{57}$ How did they navigate shifting transatlantic contexts for toleration whose locales included not only London but also Ireland, Scotland, Massachusetts, and Rhode Island? Where exactly was the SimmonsPaine printing house? When did Francis Neale join with Paine and Simmons in printing radical tolerationist materials, and when did the Paine-Simmons partnership actually end? How did Milton in particular understand his role in the larger printing campaign for tolerationism and liberty of the press? Ultimately, the careful analysis of damaged and distinctive type offers opportunities to ask and answer new questions about Milton's Areopagitica as well as the networks of radical printers materially responsible for some of Western liberalism's most dangerous and consequential tracts. 


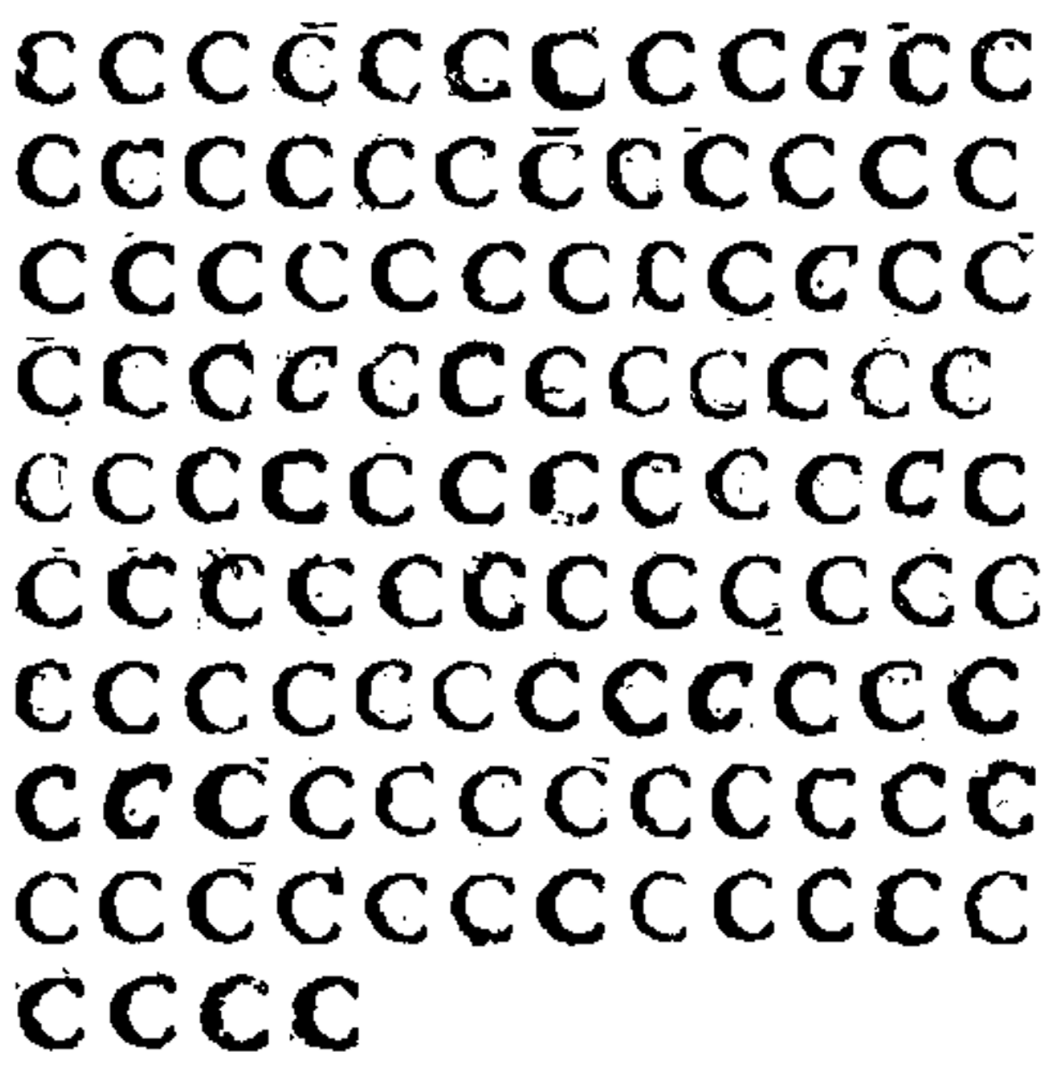

Majuscule Cs from Milton's anonymously printed Areopagitica (I644) identified by Ocular and grouped for anomaly detection. 


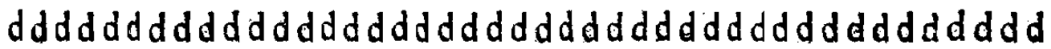
dddddda

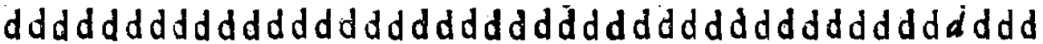

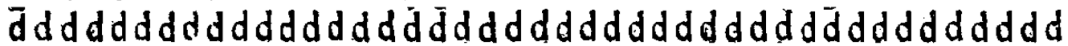

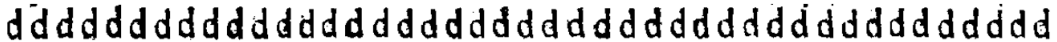

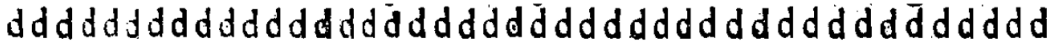

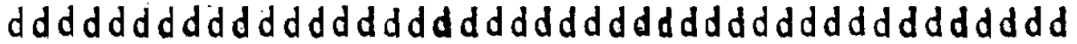

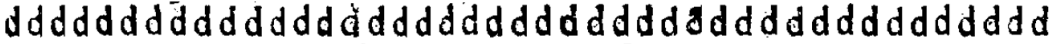

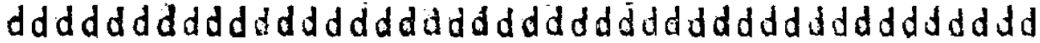

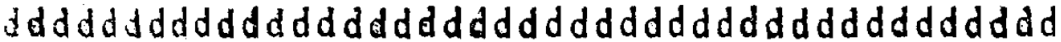

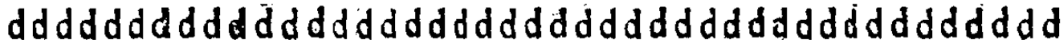

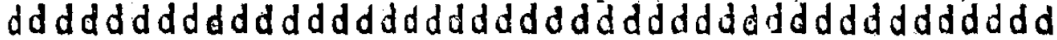

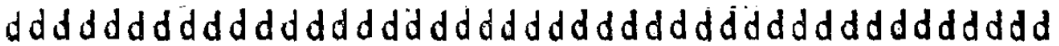

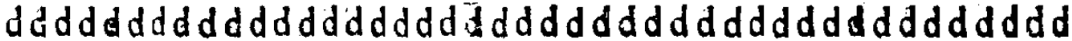

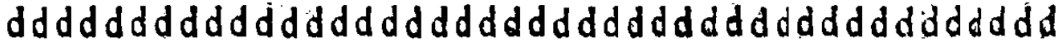

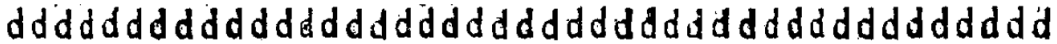

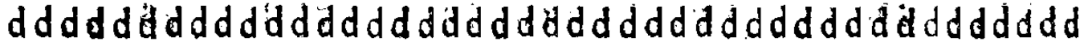

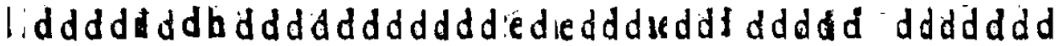

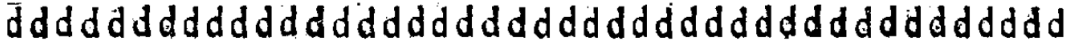

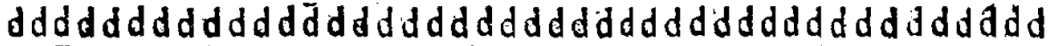

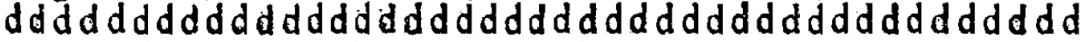

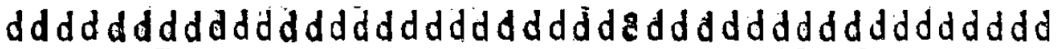

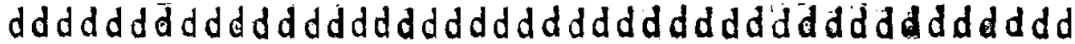

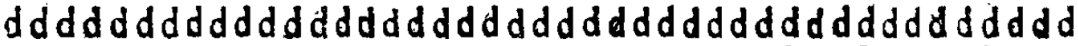

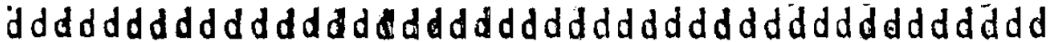

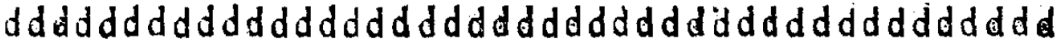
ddadddadaddadddadaddaddaddaddaddddddddaddddd

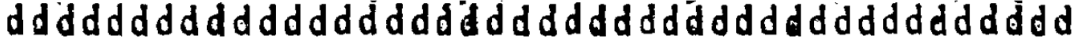

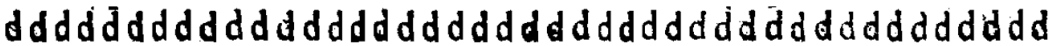

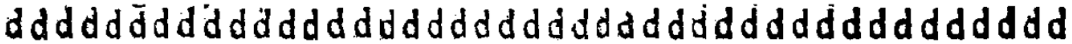

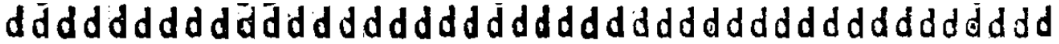

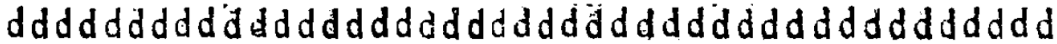

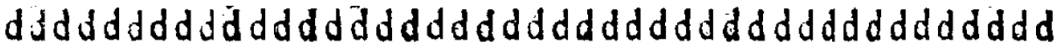

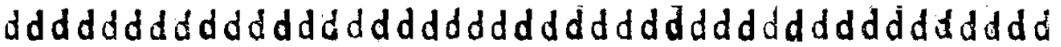

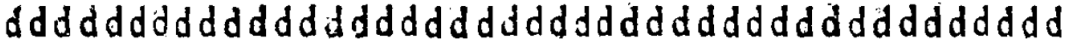

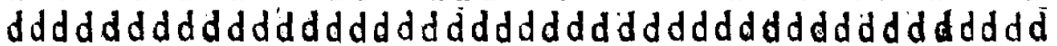

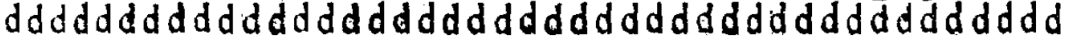

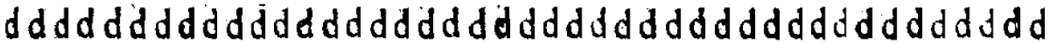

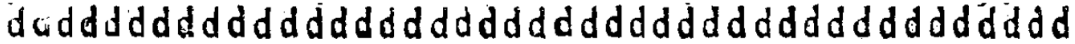

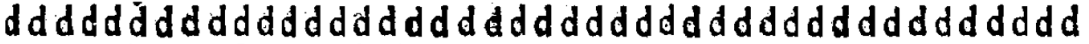
ddddadddddddddddddddddddddddddd

Miniscule d's from Milton's anonymously printed Areopagitica (I644) identified by Ocular and grouped for anomaly detection. 


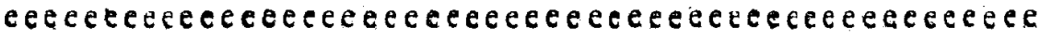

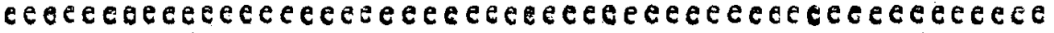

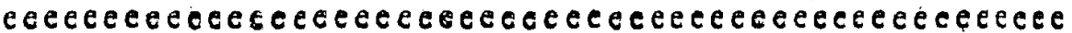

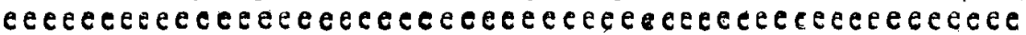

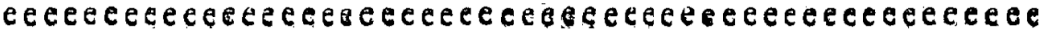

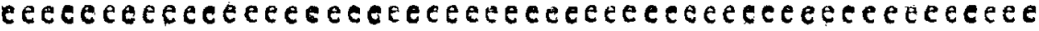

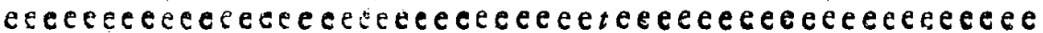

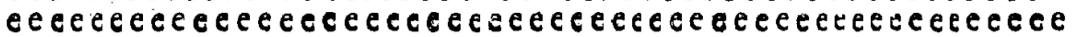

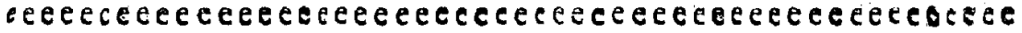

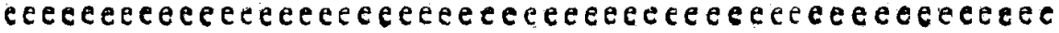

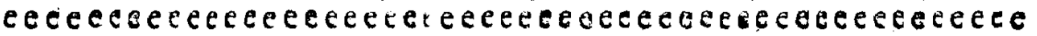

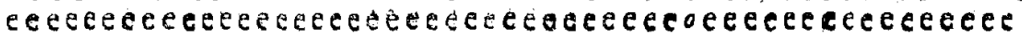

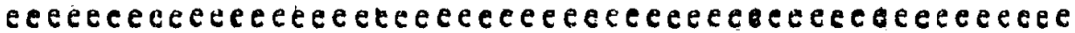

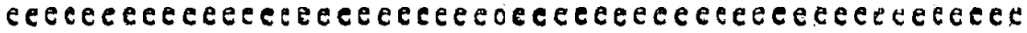

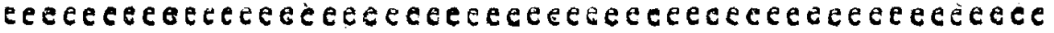

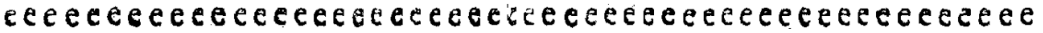

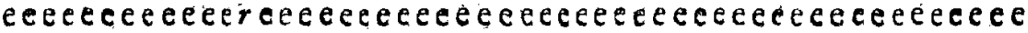

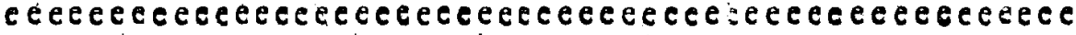

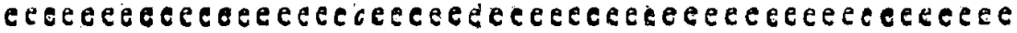

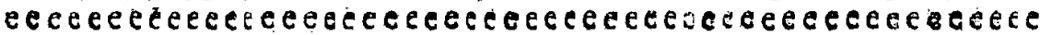

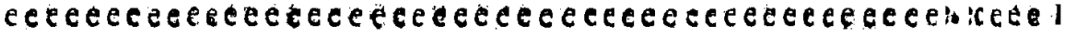

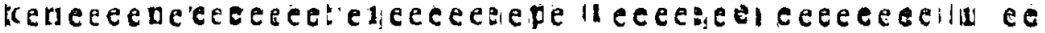

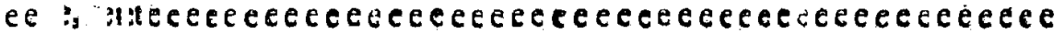

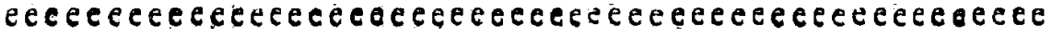

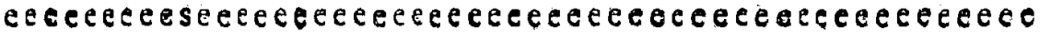

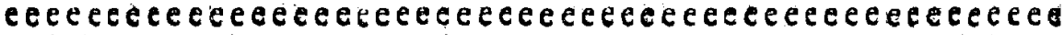

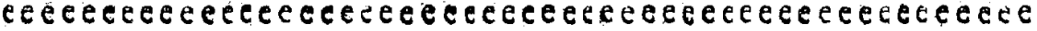

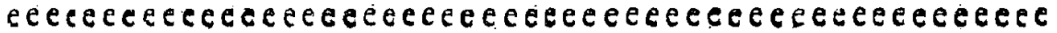

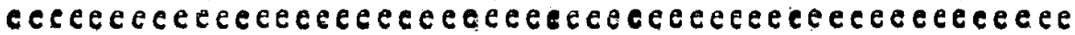

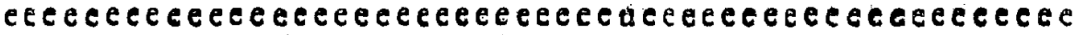

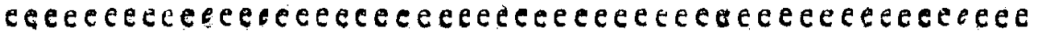

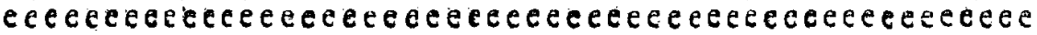

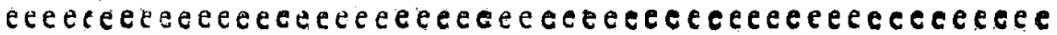

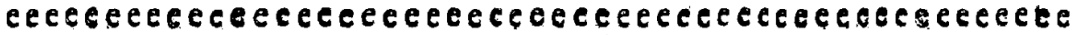

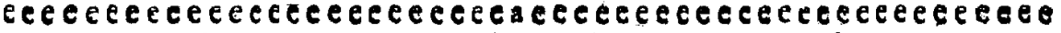

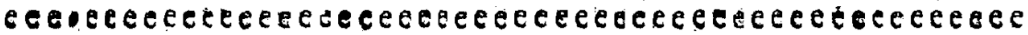

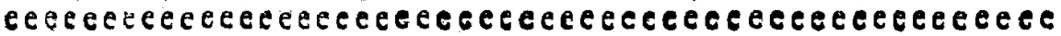

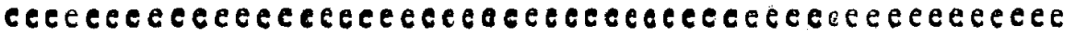

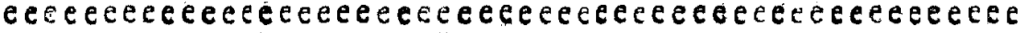

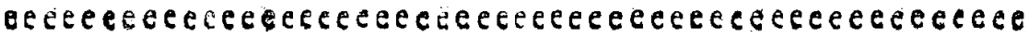

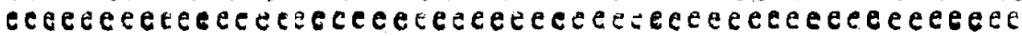

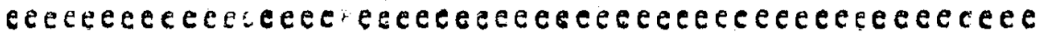

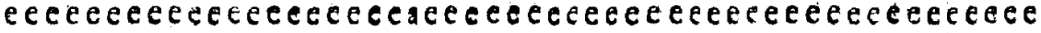

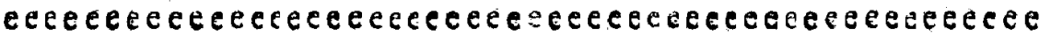

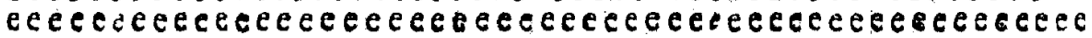

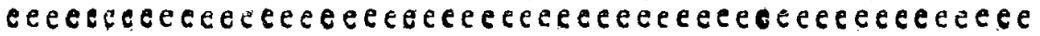

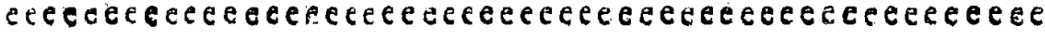

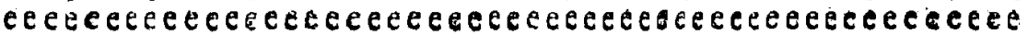

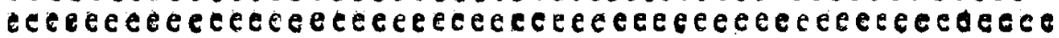

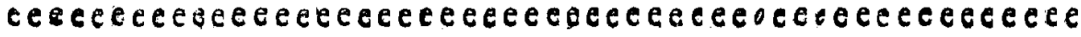
ecececect

Miniscule e's from Milton's anonymously printed Areopagitica (I644) identified by Ocular and grouped for anomaly detection. 
APPENDIX B

\section{References for Type Images}

Repositories consulted:

The collection of the Folger Shakespeare Library (photographs courtesy of Pierce Williams)

Houghton Library, Harvard University (photographs courtesy of Sara Walters and Lucas Janson)

The Huntington Library, San Marino, California (photographs courtesy of David Como, William Clayton, and Kristina Straub)

Harry Ransom Center, The University of Texas at Austin (photographs courtesy of Aaron Pratt)

The Berg Collection of English and American Literature, New York Public Library (photographs courtesy of Pierce Williams)

Rare Books and Special Collections, Library of Congress (photographs courtesy of Pierce Williams)

The McAlpin Collection of British history and theology, Burke Library at Union Theological Seminary, Columbia University (photographs courtesy of Bernadette Cay)

Special Collections Research Center, University of Michigan (photographs courtesy of Kyle Grazier)

Letters are identified by letter/book/page/line. Line numbers are exclusive of blank lines.

For abbreviations, see appendix C.

Figure 5

Row I: "N”/AREO(2)/5/I7; "N"/AREO(2)/2/4; "N"/AREO(2)/I7/I4;

“N”/AREO(2)/32/35

Row 2: "C"/AREO(2)/2/5; “C”/AREO(2)/8/27; “C”/AREO(2)/33/25

Row 3: "B”/AREO(2)/4/12; “B”/AREO(2)/7/r; "B”/AREO(2)/26/5;

"B”/AREO(2)/39/10

Row 4: "E”/AREO(2)/24/25; "E”/AREO(2)/r9/20; "E”/AREO(3)/24/r8;

"E”/AREO(3)/39/13

Row 5: "C"/AREO(2)/2/5; “C”/AREO(2)/3/32; "C"/AREO(2)/16/6;

"C" $/$ AREO(3)/32/9

Row 6: "W"/AREO(2)/6/18; "W"/AREO(2)/r2/26; "W"/AREO(2)/29/3r; "W"/AREO(I) $/ 37 / 3$ 
Figure 6

Row I: "B"/AREO(2)/4/12; "B"/AREO(2)/7/19; "B"/KKHH(2)/4I/4 Row 2: "R"/AREO(2)/27/15; "R"/AREO(2)/33/24; "R”/KKHH(I)/I $/ 29$ Row 3: "C"/AREO(2)/2/5; "C"/AREO(2)/3/32; “C”/WCCN/[Arv]/6 Row 4: "W"/AREO(2)/6/18; "W"/AREO(2)/r2/26; "W"/AACS/2/18

Figure 7

Row I: “D”/AREO(2)/Io/15; “D”/AREO(2)/1/18; “D”/DPDS/28/22; "D"/CRR $/ 37 / 4$

Row 2: "C"/AREO(2)/2/5; "C"/AREO(2)/I/3O; "C"/DPDS/20/3I Row 3: "B”/AREO(2)/4/ז2; "B”/AREO(2)/7/7; "B”/AWRH(3)/52/17 Row 4: “C”/AREO(2)/2/5; "C"/AREO(3)/32/9; “C”/DPDS/52/13 Row 5: "W"/AREO(2)/6/18; "W"/AREO(2)/29/31; "W"/QCCC/14/26 Row 6: "G”/AREO(2)/r/28; "G”/DPDS/40/10; “G”/DRBF/40/16

Figure 8

Row I: "F"/AWRH(I)/59/24; "F”/EMCR/[B $4 \mathrm{v}] / 5 ; " F ” / D R B F / 5 / 37$; "F"/KKHH(I)/[A8r]/4O; "F"/AWRH(I)/37/4I

Figure 9

Row I: "W"/DRBF/29/3; "W"/QCCC/14/26; "W"/AACS/2/18; "W"/DRBF/68/rg; "W"/IICM(b)/4/r6

Figure io

Row I: "L"/AREO(2)/5/17; “L”/AREO(2)/35/8; "L"/GMER(I)/Io8/34 Row 2: "G"/AREO(2)/39/13; "G"/AREO(I)/38/4; "G"/DPDS/2I/7 Row 3: "C"/AREO(2)/2/5; "C"/AREO(2)/8/27; "C"/DDDi(I)/2/30 Row 4: "W"/AREO(2)/6/18; "W"/AREO(4)/26/23; "W"/DDDi(2)/9/4 Row 5: "C"/AREO(2)/2/5; "C"/AREO(3)/Io/39; "C"/TNCW/68/8

Figure II

Row r: "h"/OEMS(I)/2/r; "h"/OEMS(I)/I/I5; "h"/TERM/3/I4 Row 2: "T"/OEMS(I)/sig. A/33; "T"/OEMS(2)/5/Io; “T”/AWRH(2)/35/2 Row 3: "h"/OEMS(I)/2/r; "h"/OEMS(I)/4/3; "h"/OPEP/[A4r]/I7 Row 4: "G"/OEMS(I)/I/3; "G”/OEMS(2)/I/9; "G”/DRBF/40/r6 Row 5: "h"/OEMS(I)/2/r; "h"/OEMS(I)/7/28; "h"/RSMS/5/10 Row 6: "T"/OEMS(I)/sig. A/33; “T”/OEMS(I)/3/39; “T”/DDD2(3)/27/39 Row 7: “d”/OEMS(I)/2/r; “d”/OEMS(I)/2/8; “d”/RSMS/2/15 


\section{Figure I2}

Row I: "C"/AKLA(I)/sig. A4/r6; "C"/DTPB/ro/r2; "C"/TNCW/ri/7

Row 2: "st"/AKLA(I)/Io/2; "st"/OPEP/[A 2 r]/14; "st"/TNCW/39/3

Row 3: "h"/AKLA(I)/8/I4; "h"/DDD2(I)/4/24; "h"/RSMS/5/38

Row 4: "d"/AKLA(I)/8/2; "d"/TERM/3/Ir; "d"/RSMS/5/22

Row 5: "b"/AKLA(I)/I/4; "b"/TERM/3/2r; "b"/GMER(2)/66/33

Row 6: "h"/AKLA(I)/8/I4; "h"/DDD2 $(3) / 4 / 2 ;$ "h"/GMER(2)/82/22

Row 7: “i”/AKLA(I)/[A5v]/9; "i”/DDD2(3)/ז2/23; “i”/DDDI(2)/3/33

Figure I3

Row r: "C"/AREO(2)/2/5; “C”/AREO(2)/39/3r; "C"/DDD $2(\mathrm{I}) /\left[\mathrm{A}_{4} \mathrm{r}\right] / 2 \mathrm{I}$; "C"/DPDS/13/25; "C"/LCSM/9/30; "C"/BTPC/70/30

Row 2: "T"/AREO(2)/I/18; “T”/OPEP/[A4r]/25; "T"/BTPC/r8/7; “T”/JBFC(I)/4I/2O

Row 3: "W"/AREO(2)/6/r8; "W"/AREO(2)/ז2/26; "W"/AKLA(2)/38/ז3; "W"/AACS/2/r8; "W"/BTPC/18/7

Row 4: "K”/AREO(2)/22/21; “K”/DPDS/42/r6; “K”/LCSM/[Arr]/42; "K”/BTPC/144/4; "K"/JBFC(2)/59/7

Row 5: "C"/AREO(2)/2/5; "C"/AREO(2)/3/32; "C"/DPDS/52/13;

"C"/BTPC/235/26; “C”/JBFC(I)/36/15

Row 6: "B"/AREO(2)/4/I2; "B”/AREO(2)/9/35; "B”/KKHH(I)/26/3; "B"/LCSM/44/24; "B”/JBFC(I)/15/9

Row 7: “T”/AREO(2)/I/I8; “T”/AREO(I)/28/35; “T”/AKLA(2)/title/ epigraph:"MAT[T].r3.52.”; “T”/LCSM/ro/5; “T”/BTPC/20/18

Figure I4

Row r: "G"/TCS/37/15; “G”/DDDi(2)/35/39; “G”/TCS/25/6

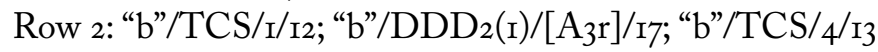

Row 3: "H”/TCS/ז3/ı6; "H”/FFGG/40/r; "H”/TCS/92/9

Row 4: "b"/TCS/r/12; "b"/OPEP/15/1o; "b"/TCS/89/1o

Row 5: "T"/TCS/ז $3 /$ Io; “T”/OPEP/[A4r]/25; "T"/TCS/29/3

Row 6: "d"/TCS/13/7; "d"/OPEP/[A $3 \mathrm{r}] / 29 ;$; "d"/TCS/85/13

Row 7: “D”/TCS/r7/ro; “D”/DPDS/28/22; "D”/TCS/r8/17

Row 8: "h"/TCS/I7/22; "h"/DDD2(I)/4/24; "h"/TCS/83/3

Row 9: "T"/TCS/ıз/г; "T"/DRBF/57/18; "T"/TCS/ı7/7

\section{Figure 15}

Row r: "g”/AKLA(r)/[A6r]/r3; "g"/DDD2(3)/3/23; "g"/ERFN/r7/29

Row 2: "G”/AKLA(I)/72/r6; "G”/DDD2(I)/19/3; "G”/ERFN/ז/25 
Row 3: "f"/AKLA(I)/A2r/2; "f"/DDD2(3)/A2r/ro; "f"/ERFN/I/26 Row 4: "A"/AKLA(I)/[A5v]/8; "A"/FFGG/58/r; "A"/ERFN/2/33 Row 5: "d"/AKLA(I)/[A5v]/8; “d”/DDD2(I)/[A4r]/I7; "d”/ERFN/ז2/25

Figure 16

Row r: "m”/TETR(I)/6/4; “m”/TETR(I)/47/15 ;"m”/DDD2(2)/35/20; "m"/IPTT/6o/9

Row 2: “T”/TETR(I)/76/23; “T”/TETR(I)/38/r2; “T”/DRBF/57/18; “T”/SVJC/16/25

Row 3: “C”/TETR(I)/24/I3; "C”/TETR(2)/28/I2; “C”/OPEP/r8/Ir; "C"/IPTT/3I/29

Row 4: "W"/TETR(I)/9/ro; "W"TETR(I)/73/28; "W"/QCCC/I4/26; "W"/IPTT/34/29

Row 5: “C”/TETR(I)/24/I3; "C"/TETR(I)/42/I5; "C"/ADLG/[BIr]/2I Row 6: "B”/TETR(I)/2/r6; "B”/TETR(r)/82/r; "B”/HORG/ro/39 Row 7: “C”/TETR(I)//; “C”/TETR(I)/20/I4; “C”/TNCW/39/4

Figure 17

Row r: "C”/QOHC/[A2v]/28; “C”/DTPB/2o/4; “C”/KKHH(2)/13/26; “C”/IPTT/5/8

Row 2: "W"/QOHC/4/ז2; "W"/AKLA(2)/38/ז3; "W"/AACS/2/18

Row 3: "C"/QOHC/[A2v]/28; “C”/KKHH(2)/17/33; “C”/IPTT/39/28

Row 4: "m”/QOHC/title/imprint:"Parla[m]ent"; "m”/DDD2(2)/35/20; "m"/IPTT/6o/9

Row 5: "C"/QOHC/[A2v]/28; "C"/TNCW/9/ı2; "C"/SVJC/2/26

Row 6: "T"/QOHC/6/6; “T”/AREO(2)/32/37; “T”/IPTT/32/7

Row 7: "C"/QOHC/[A2v]/28; "C"/AKLA(2)/Io/I7; “C”/KKHH(2)/22/38

Figure 18

Row I: "C"/AREO(2)/2/5; "C"/DPDS/52/13; "C"/AREO(2)/2/5; “C”/TETR(I)/3I/15; "C"/WCCN/[Arv]/6

Row 2: "H”/AREO(2)/I/I; "H”/FFGG/40/r; "H”/AREO(2)/4I/9; "H”/TETR(I)/2I/3o; "H”/COLA/Io/I7

Row 3: "W"/AREO(2)/6/18; "W"/AACS/2/18; "W"/AREO(2)/12/26; "W"TETR $(\mathrm{I}) / 73 / 28 ;$ "W"/COLA $/ 4 / 5$

Row 4: "B"/AREO(2)/4/ז2; "B"/KKHH(I)/26/3; "B”/AREO(2)/4/זO; “B”/TETR(I)/64/13; "B”/COLA/19/38

Row 5: "L”/AREO(2)/5/I7; “L”/GMER(I)/IO8/34; "L”/AREO(2)/35/8; "L"/TETR(I)/27/I3; “L”/COLA/3/25 
Row 6: “T”/AREO(2)/I/I8; “T”/DRBF/57/18; “T”/AREO(2)/32/37; "T"/TETR(I)/ri/29; "T”/COLA/ı2/26

Row 7: "C"/AREO(2)/2/5; “C”/DPDS/13/25; "C"/AREO(2)/39/3I; “C”/TETR $(\mathrm{I}) / 36 / 3 ;$; C"/COLA/ $13 / 39$

Row 8: "D”/AREO(2)/Io/I5; "D”/AKLA(2)/20/25; "D”/AREO(2)/I/I8; "D"/COLA/23/13 


\section{APPENDIX C}

\section{Key to Copies Cited}

AACS $=$ Anon. An Alarme to Awake Church-Sleepers (London: Matthew Symmons, 1644), Folger Shakespeare Library, shelf mark: STC 6913.7 .

ADLG $=$ Marsh, John. An Argument or Debate in Law of the Great Qvestion Concerning the Militia (London: Tho[mas] Paine and M[atthew] Simmons for Tho[mas] Underhill, r642), New York Public Library, Berg Collection, shelf mark: RB I2-I672c.2. $\operatorname{AKLA}(\mathrm{I})=$ Williams, Roger. $A$ Key into the Language of America (London: Gregory Dexter, I643), New York Public Library, Berg Collection, shelf mark: *KC ${ }_{1} 643$ (Williams, R. Key into the language of America).

$\operatorname{AKLA}(2)=$ Williams, Roger. $A$ Key into the Language of America (London: Gregory Dexter, 1643), University of Michigan, Special Collections Research Center, shelf mark: C I643 Wi.

AREO(I) = Milton, John. Areopagitica (London, I644), New York Public Library, Berg Collection, shelf mark: ${ }^{*} \mathrm{KC}$ I644 (Milton, J. Areopagitica).

$\operatorname{AREO}(2)=$ Milton, John. Areopagitica (London, I644), University of Michigan, Special Collections Research Center, shelf mark:

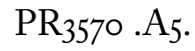

$\operatorname{AREO}(3)=$ Milton, John. Areopagitica (London, I644), Library of Congress, Rare Books and Special Collections, shelf mark: Z657 .M66 I644.

$\operatorname{AREO}(4)=$ Milton, John. Areopagitica $($ London, 1644$)$, Henry E.

Huntington Library, Rare Books and Manuscripts, shelf mark: 105635.

AWRH(I) = Weld, Thomas. An Answer to W.R. His Narration of the Opinions and Practises of the Churches Lately Erected in NewEngland (London: Tho[mas] Paine for H[enry] Overton, 1644), New York Public Library, Berg Collection, shelf mark: *KC I644 (Welde, T. Answer to W.R. his narration).

$\operatorname{AWRH}(2)=$ Weld, Thomas. An Answer to W.R. His Narration of the Opinions and Practises of the Churches Lately Erected in NewEngland (London: Tho[mas] Paine for H[enry] Overton, 1644), 
University of Michigan, Special Collections Research Center, shelf mark: C I644 We.

$\operatorname{AWRH}(3)=$ Weld, Thomas. An Answer to W.R. His Narration of the Opinions and Practises of the Churches Lately Erected in NewEngland (London: Tho[mas] Paine for H[enry] Overton, 1644), Folger Shakespeare Library, shelf mark: WI262 Bd.w. Gi225. BTPC = Williams, Roger. The Bloudy Tenent, of Persecution, for Cause of Conscience. (London, I644), University of Michigan, Special Collections Research Center, shelf mark: C r644 Wi.

COLA = Milton, John. Colasterion (London, I645), University of

Michigan, University of Michigan, Special Collections Research

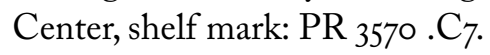

$\mathrm{CRR}=$ Price, John. The City-Remonstrance Remonstrated (London:

Tho[mas] Paine for Henry Overton, 1646), The University of Texas at Austin, Harry Ransom Center, Rare Books and Manuscripts, shelf mark: Ah p93r 646c.

$\operatorname{DDDI}(\mathrm{I})=$ Milton, John. The Doctrine E Discipline of Divorce, ist ed.

(London: T[homas] P[aine] and M[atthew] S[immons], r643),

New York Public Library, Berg Collection, shelf mark: *KC I643

(Milton, J. Doctrine and discipline of divorce) Copy I.

$\operatorname{DDDi}(2)=$ Milton, John. The Doctrine $\Xi$ Discipline of Divorce, ist ed.

(London: T[homas] P[aine] and M[atthew] S[immons], r643),

Harvard University, Houghton Library, shelf mark: *EC65 M6427 643d Lobby XI.2.I8.

$\mathrm{DDD}_{2}(\mathrm{I})=$ Milton, John. The Doctrine E Discipline of Divorce, 2 nd ed.

(London: [Gregory Dexter], r644), New York Public Library, Berg Collection, shelf mark: *KC I644 (Milton, J. Doctrine \& discipline of divorce) Copy 2.

$\mathrm{DDD}_{2}(2)=$ Milton, John. The Doctrine E Discipline of Divorce, 2 nd ed.

(London: [Gregory Dexter], I644), Folger Shakespeare Library, shelf mark: I40- 386q.

$\mathrm{DDD}_{2}(3)=$ Milton, John. The Doctrine E Discipline of Divorce, 2 nd ed.

(London: [Gregory Dexter], I644), Harvard University, Houghton

Library, shelf mark: GEN *EC65 M6427 643db (A) Lobby XI.2.I9.

DPDS = Mad man [pseud.]. Divinity and Philosophy Dissected, and

Set Forth, by a Mad Man (Amsterdam [London(?)], I644), The

McAlpin Collection of British history and theology, Burke Library at Union Theological Seminary, Columbia University, shelf mark: I644 D62. 
DRBF $=$ Hughes, George A Dry Rod Blooming and Fruit-Bearing

(London: T[homas] Paine for John Rothwell, r644), The McAlpin

Collection of British history and theology, Burke Library at Union

Theological Seminary, Columbia University, shelf mark: 1644 H89.

$\mathrm{DTPB}=$ Anon. $A$ Discourse Tending to Prove the Baptisme in, or under the

Defection of Antichrist to Be the Ordinance of Jesus Christ (London:

R[ichard] Oulton \& G[regory] Dexter, I642), Folger Shakespeare

Library, shelf mark: B75oa Bd.w. S5489 copy 2.

EMCR = Anon. England's Monarch, or, A Conviction and Refutation by the

Common Law (London: Thomas Paine, I644), University of Illinois,

Urbana-Champaign, Rare Book and Manuscript Library, shelf mark: IUAo564I.

ERFN = Smith, William. An Exact Relation of That Famous and Notable

Victorie Obtained at Milford-Haven against the Earle of Carbery His

Forces (London: Moses Bell, 1644), British Library, Rare Books and

Manuscripts, shelf mark: E.3.(I2.).

FFGG $=$ Duke, Francis. The Fulnesse and Freenesse of Gods Grace in Jesus

Christ (London: Richard Oulton and Gregory Dexter, I642),

Harvard University, Houghton Library, shelf mark: GEN *EC65

D8850 642f.

GMER(I) = Vicars, John. God in the Mount, or, England's Remembrancer

(London: T[homas] Paine, and M[atthew] Simmons for John

Rothwell and Thomas Underhill, 1642), Folger Shakespeare

Library, shelf mark: 180- 393q.

$\operatorname{GMER}(2)=$ Vicars, John. God in the Mount, or, England's Remembrancer

(London: T[homas] Paine, and M[atthew] Simmons for John

Rothwell and Thomas Underhill, I642), Harvard University,

Houghton Library, shelf mark: GEN *EC65.Al785.696g.

HORG = Price, John. Honey out of the Rock, or, God's Method in Giving

the Sweetest Comforts in Sharpest Combates (London: Francis Neile for Henry Overton, 1644), Folger Shakespeare Library, shelf mark: I36- 420q.

$\operatorname{IICM}(\mathrm{a})=$ Woodward, Hezekiah. Inquiries into the causes of our miseries [part I of 2] (London: Printed for Tho[mas] Underhill, I644), The Huntington Library, San Marino, California, shelf mark: 57707.

$\operatorname{IICM}(\mathrm{b})=$ Woodward, Hezekiah. Inquiries into the causes of our miseries [part 2 of 2] (London: Printed for Tho[mas] Underhill, 1644), Houghton Library, Harvard University, shelf mark: *EC65 W8735 645i. 
IPTT = Reynolds, Edward. Israel's Prayer in Time of Trouble, with Gods Gracious Answer Therunto (London: Francis Neile for Robert Bostock, 1645), New York Public Library, Berg Collection, shelf mark: *YLRF (Reynolds, E. Israel's prayer in time of trouble). JBFC(I) = Robinson, Henry. John the Baptist, Forerunner of Christ Jesus

(London, 1644), Library of Congress, Rare Books and Special Collections, shelf mark: BV74I.J57.

JBFC(2) = Robinson, Henry. John the Baptist, Forerunner of Christ Jesus

(London, 1644), Andover Theological Library, Harvard University, shelf mark: BR757 .R6 (I).

$\mathrm{KKHH}(\mathrm{I})=$ Cotton, John. The Keyes of the Kingdom of Heaven, and Power Thereof (London: M[atthew] Simmons for Henry Overton, 1644), New York Public Library, Berg Collection, shelf mark: *KC I644 (Cotton, J. Keyes of the kingdom).

$\mathrm{KKHH}(2)=$ Cotton, John. The Keyes of the Kingdom of Heaven, and the Power Thereof (London: M[atthew] Simmons for Henry Overton, I644), Library of Congress, Rare Books and Special Collections, shelf mark: $\mathrm{BX}_{7230} \mathrm{C}_{75} \mathrm{I}_{644}$.

LCSM = Robinson, Henry. Liberty of Conscience: Or The Sole Means to

Obtaine Peace and Truth (London, 1643), University of Michigan,

Special Collections Research Center, shelf mark: C2 I643 Ro. OEMS(I) = Milton, John. Of Education, To Master Samuel Hartlib

(London, 1644), Folger Shakespeare Library, shelf mark: 269-349q.

OEMS(2) = Milton, John. Of Education, To Master Samuel Hartlib

(London, I644), Houghton Library, Harvard University, shelf mark: GEN I4496.44.50* Lobby XI.2.25.

OPEP = Milton, John. Of Prelatical Episcopacy (London : R[ichard] O[ulton] \& G[regory] D[exter] for Thomas Underhill, r64I), Folger Shakespeare Library, shelf mark: 133- I54q.

QCCC = Quatermayne, Roger. Quatermayn's Conquest over Canterburies

Court (London: Thomas Paine for Roger Quatermayne, 1642),

Folger Shakespeare Library, shelf mark: I49- 790q.

QOHC = Goodwin, Thomas. Queries of Highest Consideration (London:

[Gregory Dexter], I644), Folger Shakespeare Library, shelf mark: I37- 78 oq.

RSMS = Sclater, William. The Remedie of Schisme, or, A Mean to Settle the

Divisions of the Times (London: T[homas] Paine and M[atthew] $\mathrm{S}$ [immons] for Tho[mas] Slater, I642), The McAlpin Collection of 
British history and theology, Burke Library at Union Theological Seminary, Columbia University, shelf mark: 1638 S419. SVJC = Maynard, John. A Shadow of the Victory of Christ (London:

F[rancis] Neile for Samuel Gellibrand, I646), Folger Shakespeare Library, shelf mark: 137- 648q.

TCS = Walwyn, William. The Compassionate Samaritane (London, 1644), The Huntington Library, San Marino, California, shelf mark: 62701 .

TERM = Anon. $A$ True and Exact Relation of the Most Sad Condition of Ireland (London: G[regory] Dexter for Henry Overton, I643), Folger Shakespeare Library, shelf mark: 18I- 084q. TETR(I) = Milton, John. Tetrachordon (London, I645), New York

Public Library, Berg Collection, shelf mark: *KC r645 (Milton, J. Tetrachordon).

$\operatorname{TETR}(2)=$ Milton, John. Tetrachordon (London, I645), Folger

Shakespeare Library, shelf mark: 139- 678q.

TNCW = Ball, John. A Tryall of the New-Church Way in New-England and in Old (London: T[homas] Paine and M[atthew] Simmons for Thomas Underhill, I644), Folger Shakespeare Library, shelf mark: I8I- 653q.

WCCN = Cotton, John. The Way of the Churches of Christ in New-England (London: Matthew Simmons, I645), New York Public Library, Berg Collection, shelf mark: *KC r644 (Cotton, J. Way of the churches).

\section{NOTES}

Research for this publication was supported by an A. W. Mellon Digital Humanities seed grant from Carnegie Mellon University, a resource allocation from the Pittsburgh Supercomputing Center (HUMr70002P), and a grant from the National Science Foundation ("Print and Probability," 18163II). The authors also wish to thank the following individuals for their assistance: Sharon Achinstein, Taylor Berg-Kirkpatrick, Bernadette Cay, William Clayton, John Coffey, David Como, Ciaran Evans, Dan Evans, Will Fithian, Tom Fulton, Kyle Grazier, Lucas Janson, Evelina Kats, Miles Lopes, Anjali Mazumder, Emily Motin, David Norbrook, John Overholt, Aaron Pratt, Daniel Shore, Kristina Straub, and Sara Walters.

I. David Adams and Nicholas von Maltzhan have each explored the question in unpublished papers, but neither paper is available in print. A summary of Adams's unpublished paper appears in John Coffey, "Scripture and Toleration Between 
Reformation and Enlightenment," in Religious Tolerance in the Atlantic World : Early Modern and Contemporary Perspectives, ed. Elaine Glaser (London, 2014), I8; for an abstract of Nicholas von Maltzahn's "Who Printed Areopagitica? The Press and Milton's Paper Work" (Modern Language Association, Vancouver, 2015), see "Milton and Book History," SHARP: The Society for the History of Authorship, Reading and Publishing, November 20I4, http://www.sharpweb.org/main/joint-sharp-mla-panelmilton-and-book-history/.

2. David R. Como, Radical Parliamentarians and the English Civil War (Oxford, 2018), 822.

3. Ernest Sirluck, "Preface to Areopagitica," in Complete Prose Works of John Milton, gen. ed. Don M. Wolfe, 8 vols. (New Haven, I953-82), 2:48o, this edition hereafter cited as YP.

4. Sharon Achinstein, "Cold War Milton," University of Toronto Quarterly 77, no. 3 (2008): 80I-36.

5. Stephen B. Dobranski, Milton, Authorship, and the Book Trade (Cambridge, 1999), $2-4$.

6. Charlton Hinman, The Printing and Proof-Reading of The First Folio of Shakespeare, 2 vols. (Oxford, r963), r:5, 34.

7. Peter W. M. Blayney, The First Folio of Shakespeare (Washington, D.C., I99I), I2.

8. Jeffrey Masten, Queer Philologies: Sex, Language, and Affect in Shakespeare's Time (Philadelphia, 20I6), 53.

9. Robert K. Turner, "Reappearing Types as Bibliographical Evidence," Studies in Bibliography I9 (1966): 208, http://www.jstor.org/stable/40371424.

Io. For a comprehensive program for adding type damage into bibliographical description, see G. Thomas Tanselle, "The Use of Type Damage as Evidence in Bibliographical Description," The Library 5th ser., 23, no. 4 (1968): 328-51, https://doi.org/10.Io93/library/ s5-XXIII.4.328.

II. Hinman, The Printing and Proof-Reading of The First Folio of Shakespeare, r:69.

I2. David R. Adams, "The Secret Printing and Publishing Career of Richard Overton the Leveller, I644-46,” The Library II, no. I (March 2010): 3-88, https://doi.org/Io.Io93/ library/Ir.I.3; David R. Como, "Print, Censorship, and Ideological Escalation in the English Civil War," Journal of British Studies 5I, no. 4 (2012): 820-57, https://doi. org/ro.ro86/666848; and Como, Radical Parliamentarians and the English Civil War. Adams and Como continue a line of scholarship admirably inaugurated by $\mathrm{H}$. R. Plomer, "Secret Printing During the Civil War," The Library and ser., 5, no. 20 (1904): 374-403, https://doi.org/Io.1093/library/s2-V.20.374.

I3. Ian Gadd, "Simmons, Matthew (b. in or before 1608, d. 1654), Bookseller and Printer," Oxford Dictionary of National Biography, accessed May 15, 2019, https://doi. org/ıo.Io93/ref:odnb/69230; and William R. Parker, “Above All Liberties: John Milton's Relations with His Earliest Publishers," Princeton University Library Chronicle 2, no. 2 (I94I): 4I-50, https://doi.org/I0.2307/26400387.

I4. von Maltzahn, "Who Printed Areopagitica?"

I5. John T. Shawcross, "Printers," in vol. 7 of A Milton Encyclopedia, ed. William B. Hunter (Lewisburg, Penna., I980), I5-I8. 
I6. John T. Shawcross, Milton: A Bibliography for the Years I624-I70o (Binghamton: N.Y., 1984); and John T. Shawcross, "The Date of the Separate Edition of Milton's 'Epitaphium Damonis," Studies in Bibliography I8 (1965): 262-65, https://www.jstor.org/ stable/4037I405.

I7. William R. Parker, "Contributions Toward a Milton Bibliography," The Library 4 th ser., I6, no. 4 (I936): 43I, https://doi.org/Io.Io93/library/s4-XVI.4.425.

I8. Dobranski, Milton, Authorship, and the Book Trade, 23 I.

I9. Sharon Achinstein and Benjamin Burton, "Who Printed Milton's Tetrachordon (1645)?” The Library I4, no. I (2013): I8-44, https://doi.org/Io.Io93/library/I4.I.I8.

20. The precise relations among Matthew, Samuel, and Mary had been cloudy before D. F. McKenzie, “Milton's Printers: Matthew, Mary and Samuel Simmons," Milton Quarterly I4, no. 3 (1980): 87-9I, https://doi.org/ro.IIII/j.Io94-348X.I980.tboo22o.x

21. Como, Radical Parliamentarians and the English Civil War, 280; and Sabrina A. Baron, "Licensing Readers, Licensing Authorities in Seventeenth-Century England," in Books and Readers in Early Modern England, ed. Jennifer Andersen and Elizabeth Sauer (Philadelphia, 2002), 220.

22. Derek Nuttall, "English Printers I600-I700 and Their Supra-Text Roman and Italic Types" (Ph.D. thesis, University of Reading, I985), 315.

23. Peter Blayney has examined the quantities of standing type in the first quarto of King Lear. See Peter W. M. Blayney, The Texts of "King Lear" and Their Origins (Cambridge, 1979), vol. I, Appendix IV-C, 528-37

24. Hinman, The Printing and Proof-Reading of the First Folio of Shakespeare; Adrian Weiss, "Shared Printing, Printer's Copy, and the Text(s) of Gascoigne's 'A Hundreth Sundrie Flowres," Studies in Bibliography 45 (I992): 7I-IO4, http://www.jstor.org/ stable/40371958; and Como, "Print, Censorship, and Ideological Escalation in the English Civil War."

25. Adrian Weiss, "Font Analysis as a Bibliographical Method: The Elizabethan PlayQuarto Printers and Compositors," Studies in Bibliography 43 (1990): 95-164, http:// www.jstor.org/stable/40371924.

26. Weiss, "Shared Printing, Printer's Copy,'"; Sara J. van den Berg and W. Scott Howard, "G. M. Revealed: Printer of the First Attacks on The Doctrine and Discipline of Divorce," Milton Quarterly 38, no. 4 (2004): 242-52, https://doi.org/Io.IIII/j.Io94348X.2004.00082.x; Achinstein and Burton, "Who Printed Milton's Tetrachordon (1645)?"; Adams, "The Secret Printing and Publishing Career of Richard Overton the Leveller, 1644-46"; and Como, Radical Parliamentarians and the English Civil War.

27. On the transformation of UMI microfilms into Early English Books Online, see Bonnie Mak, "Archaeology of a Digitization," Journal of the Association for Information Science and Technology 65, no. 8 (2014): 1515-26, https://doi.org/Io.1002/asi.2306r; and Michael Gavin, "How To Think about EEBO," Textual Cultures II, nos. I-2 (2019): 70-I05, https://doi.org/Io.I4434/textual.vniri-2.23570.

28. Dobranski, Milton, Authorship, and the Book Trade, I.

29. Taylor Berg-Kirkpatrick, Greg Durrett, and Dan Klein, "Unsupervised Transcription of Historical Documents," in Proceedings of the 5Ist Annual Meeting of the Association for Computational Linguistics (Sofia, Bulgaria, 2013), 207-17. 
30. We are grateful to David Como for the latter suggestion.

3I. Wherever possible, we adopt the terms for typographic letterforms defined in Philip Gaskell, “A Nomenclature for the Letterforms of Roman Type," The Library $5^{\text {th }}$ ser, 29, no. I (1974): 42-51, https://doi.org/Io.Io93/library/s5-XXIX.r.42.

32. See, for example, John Cotton, The Keyes of the Kingdom of Heaven, and Power Thereof (London: Printed by M[atthew] Simmons for Henry Overton, I644); John Cotton, The Vvay of the Churches of Christ in New-England (London: Printed by Matthew Simmons, I645); and John Goodwin, Calumny Arraign'd and Cast, or, A Briefe Answer to Some Extravagant and Rank Passages, Lately Fallen from the Pen of William Prynne (London: Printed by M[atthew] Simmons for Henry Overton, I645)

33. D. F. McKenzie and Maureen Bell, eds., A Chronology and Calendar of Documents Relating to the London Book Trade, I64I-I700, 3 vols. (Oxford, 2005).

34. The offending tract was Lewis Hughes's Certain Grievances, or Errors (I64I). See McKenzie and Bell, eds., Chronology and Calendar, r:31.

35. Dobranski, Milton, Authorship, and the Book Trade, 6; and McKenzie and Bell, eds., Chronology and Calendar, 1:I29.

36. "If the Book bear Independent upon its front, and be thought to speak for that way (which God Himself will clear and justified before all the world) it is silenced before it speaks. And so it is dealt more injuriously with, than have been the greatest offenders in the world: for they have had leave to speak for themselves in all ages of the world." Ezekias Woodward, Inquiries into the Causes of Our Miseries, ([London?, s.n.], I644), I-2. 37. McKenzie and Bell, eds., Chronology and Calendar, I:I29. On private printing, see Jason Peacey, Print and Public Politics in the English Revolution (Cambridge, 2013), $25 \mathrm{I}$.

38. British Museum, Catalogue of the Pamphlets, Books, Newspapers, and Manuscripts

Relating to the Civil War, the Commonwealth, and Restoration, Collected by George Thomason, I640-166I (London, I908).

39. Giovanni Torriano, A Display of Monasyllable Particles of the Italian Tongue by Way of (London: Thomas Paine, 1640 ), $\mathrm{F}_{2 \mathrm{v}}$; and Richard Baker, Meditations and Disquisitions Vpon the Lords Prayer (London, I640), Bir.

40. Achinstein and Burton, "Who Printed Milton's Tetrachordon (I645)?” Intriguingly, Paine also frequently used the borders that appeared in the undated, separate edition of Epitaphium Damonis, thus adding a third possible printer to those proposed by Harris Francis Fletcher, “The Seventeenth-Century Separate Printing of Milton's 'Epitaphium Damonis," Journal of English and Germanic Philology 6I, no. 4 (I962): 788-96, https:// www.jstor.org/stable/277I4I35; and see Shawcross, "The Date of the Separate Edition of Milton's 'Epitaphium Damonis.”

4I. Thomas Weld, An Answer to W.R. His Narration of the Opinions and Practises of the Churches Lately Erected in Nevv-England (London, I644), I.

42. We are grateful to David Como for drawing this work to our attention.

43. David Como, "An Unattributed Pamphlet by William Walwyn: New Light on the Prehistory of the Leveller Movement," Huntington Library Quarterly 69, no. 3 (2006): 36I, https://doi.org/Io.I525/hlq.2006.69.3.353.

44. The list includes A Godly Man's Choice (I644) and The Judgement of Martin Bucer (August 1644). 
45. McKenzie and Bell, eds., Chronology and Calendar, r:Ir6.

46. Como, Radical Parliamentarians and the English Civil War, 280.

47. McKenzie and Bell, eds., Chronology and Calendar, r:Io9.

48. Como, "Print, Censorship, and Ideological Escalation," 834.

49. McKenzie and Bell, eds., Chronology and Calendar, r:71.

50. Como, Radical Parliamentarians and the English Civil War, 26r. See also Sharon Achinstein, Milton and the Revolutionary Reader (Princeton, 1994), 34-37; Thomas Fulton, Historical Milton: Manuscript, Print, and Political Culture in Revolutionary England (Amherst, 2010), 91-92; Nigel Smith, "Areopagitica: Voicing Contexts 1643-45," in Politics, Poetics, and Hermeneutics in Milton's Prose, ed. David Loewenstein and James Grantham Turner (Cambridge, I990), I03-22; and Ernest Sirluck, "Introduction," in YP 2:48o-83.

51. Coffey, "Scripture and Toleration," 18.

52. Como, Radical Parliamentarians and the English Civil War, 239.

53. McKenzie and Bell, eds., Chronology and Calendar, i:ır6.

54. For the appearance of this piece of type in the first edition, see Milton, The Doctrine and Discipline of Divorce, 26.

55. Achinstein and Burton, "Who Printed Milton's Tetrachordon (I645)?" 22-29.

56. See Henry Robert Plomer, A Dictionary of the Booksellers and Printers Who Were at Work in England, Scotland and Ireland from I64I to I667 (London, I907), I35. For the I644 date, see Nuttall, "English Printers I60o-I70o," 94.

57. Thomas N. Corns, "John Milton, Roger Williams, and Limits of Toleration," in Milton and Toleration, ed. Sharon Achinstein and Elizabeth Sauer (Oxford, 2007), 72-85; and YP 2:555. 